Article

\title{
A New Design for Magnetic Poly(vinyl pivalate) for Biomedical Applications: Synthesis, Characterization, and Evaluation of Cytotoxicity in Fibroblasts, Keratinocytes, and Human Melanoma Cells
}

\author{
Robson T. Araujo ${ }^{1}$, Maria S. B. Neta ${ }^{2}$, José A. H. Coaquira ${ }^{3}$, Sacha B. Chaves ${ }^{2}{ }^{(1)}$ and Fabricio Machado ${ }^{1, *,+(\mathbb{C})}$ \\ 1 Instituto de Química, Universidade de Brasília, Campus Universitário Darcy Ribeiro, \\ Brasília 70910-000, DF, Brazil; robson.araujo@aluno.unb.br \\ 2 Departamento de Genética e Morfologia, Instituto de Biologia, Universidade de Brasília, \\ Campus Universitário Darcy Ribeiro, Brasília 70910-000, DF, Brazil; sousa.brito@aluno.unb.br (M.S.B.N.); \\ sachabraun@unb.br (S.B.C.) \\ 3 Instituto de Física, Universidade de Brasília, Campus Universitário Darcy Ribeiro, \\ Brasília 70910-000, DF, Brazil; coaquira@unb.br \\ * Correspondence: fmachado@unb.br; Tel.: +55-61-3107-3868 \\ + Current address: School of Chemistry, University of Nottingham, University Park, Nottingham NG7 2RD, UK.
}

Citation: Araujo, R.T.; Neta, M.S.B.; Coaquira, J.A.H.; Chaves, S.B.; Machado, F. A New Design for Magnetic Poly(vinyl pivalate) for Biomedical Applications: Synthesis, Characterization, and Evaluation of Cytotoxicity in Fibroblasts, Keratinocytes, and Human Melanoma Cells. Colloids Interfaces 2022, 6, 7. https://doi.org/10.3390/ colloids6010007

Academic Editor: Reinhard Miller

Received: 30 November 2021

Accepted: 19 January 2022

Published: 21 January 2022

Publisher's Note: MDPI stays neutral with regard to jurisdictional claims in published maps and institutional affiliations.

Copyright: () 2022 by the authors. Licensee MDPI, Basel, Switzerland. This article is an open access article distributed under the terms and conditions of the Creative Commons Attribution (CC BY) license (https:/ / creativecommons.org/licenses/by/ $4.0 /)$.
Abstract: Polymers containing magnetic properties play an important role in biomedical therapies, such as embolotherapy or hyperthermia, for their differentiated properties. In this work, magnetite $\left(\mathrm{Fe}_{3} \mathrm{O}_{4}\right)$ nanoparticles were synthesized by the coprecipitation method and dispersed into a thermoplastic matrix of poly(vinyl pivalate) through an emulsion polymerization process. The main goal was the individual encapsulation of magnetite nanoparticles to improve the magnetic response of the magneto-polymeric materials using polymerizable carboxylic acids as coating agents, minimizing the leaching of nanoparticles throughout the nanocomposite formation. For this purpose, synthesized magnetite had its surface modified by acrylic acid or methacrylic acid to improve its individual encapsulation during the polymerization step, thus generating a series of magnetic nanocomposite materials containing different amounts of magnetite intended for biomedical applications. X-ray diffractometry and TEM measurements provided a mean size of approximately $8 \mathrm{~nm}$ for the pure magnetite nanoparticles and a spherical morphology. Acid-functionalized $\mathrm{Fe}_{3} \mathrm{O}_{4}$ had a size of approximately $6 \mathrm{~nm}$, while the nanocomposites showed a size of approximately $7 \mathrm{~nm}$. Magnetization measurement provided a saturation magnetization value of approximately $75 \mathrm{emu} / \mathrm{g}$ and confirmed superparamagnetic behavior at room temperature. DSC analysis showed a glass transition temperature of $65^{\circ} \mathrm{C}$ for poly(vinyl pivalate)-based nanocomposites. The tests realized with homopolymer and magnetic composites against different cell lineages (i.e., fibroblasts, keratinocytes, and human melanoma) to evaluate the levels of cytotoxicity showed good results in the different exposure times and concentrations used, since the obtained results showed cell viability greater than $70 \%$ compared to the control group, suggesting that the synthesized materials are very promising for medical applications.

Keywords: emulsion polymerization; superparamagnetism; toxicity; poly(vinyl pivalate); hyperthermia; melanoma

\section{Introduction}

Iron is one of the most abundant elements in the Earth's crust and is important in several metabolic processes in the human body. In the form of its different compounds, especially oxides, it has been researched and used in the biomedical field [1]. Some iron oxides, such as magnetite and maghemite, show, under certain conditions, peculiar properties such as superparamagnetism. In addition, these compounds exhibit good 
colloidal stability and biocompatibility [2], which makes several applications involving nanoparticles possible.

Non-functionalized nanoparticles normally exhibit different properties than those that have gone through a functionalization stage. However, a reduction in magnetism on the surface of magnetite nanoparticles may hinder many possible uses in different applications. To get around this difficulty, functionalization with several compounds is used including polymers and carboxylic acids [3]. This procedure of dispersing magnetic nanoparticles (MNPs) in polymeric matrices generates a series of interesting features for biomedical applications, among which include $[4,5]$ (i) an increased compatibility with organic matrices, (ii) a reduced tendency to leach, (iii) protection of the particle surface against oxidation processes, among others.

Due to the fact of their physicochemical properties, biocompatibility, reduced toxicity, and the possibility of controlling morphology, several materials, such as polyethylene glycol (PEG), chitosan, dextran, and poly(vinyl alcohol) (PVA), can be used in conjunction with inorganic materials, such as iron oxides, for the development of materials with applications in several areas. Magnetic polymeric lattices have been found to have great use in biomedical applications such as magnetic separation of compounds [6], diagnosis agents [7], agriculture and food [8], drug delivery systems [9], catalysis [10], hyperthermia, and embolotherapy [11]. Several methods have been developed to synthesize magnetic polymeric lattices such as emulsion, suspension, dispersion, microemulsion, and miniemulsion.

Many studies in the biomedical area focus on toxicity and the collateral effects after administration on living organisms and cells. The main concerns are related to cytotoxicity and nephrotoxicity due to the nanoparticles' sizes once they can cause many disease states, such as ischemia and reperfusion injury, occurring mainly because of reactive oxygen species (ROS). In the case of magnetite nanoparticles, because of their catalytic properties, the generation of free radicals by Fenton processes is possible [12]. When this type of process occurs in living organisms, with humans being the most studied, it can lead to cardiovascular and degenerative diseases as well as cancer and aging. However, several studies focusing on nanoparticle functionalization and encapsulation are currently underway, aimed at understanding how these promising materials can successfully be used in therapies associated with the treatment of some types of cancer [12,13].

To overcome some of the limitations on magnetic nanoparticle applications, including compatibility with organic matrices, tendency to leach, and particle surface protection against oxidation [5], polymers are normally used. The emulsion polymerization process can be effectively used for individual encapsulation of magnetic nanoparticles with a tailored yield and high encapsulation efficiency, which can guarantee greater efficiency of the magnetic attraction of magneto-polymeric nanocomposites.

Several authors have investigated the cytotoxicity of nanoparticles in cells of different types. Among these authors we can cite the recent work of Resende et al. [14], who studied polymeric core-shell nanoparticles obtained through miniemulsion polymerization combined with seeded polymerization intended for embolotherapy. As exemplified by the authors, a new class of poly(methyl methacrylate)- $\mathrm{Fe}_{3} \mathrm{O}_{4} /$ poly(vinyl pivalate) coreshell superparamagnetic nanoparticles exhibited high cell viabilities for murine melanoma (B16F10 cells lineage) and keratinocyte (HaCaT lineages). Although the work developed by Resende and collaborators provides significant contributions, it is important to bear in mind that the miniemulsion process might not be suitable for the individual encapsulation of magnetic nanoparticles due to the characteristic size of monomeric nanodroplets, which in the range of 50-200 nm, making the final magneto-polymeric material present a large number of nanoparticles encapsulated in the form of nanoclusters, which may affect the magnetic response of the material.

Rehana et al. [15] showed that magnetic nanoparticles functionalized with different organic acids, such as ascorbic, hexanoic, salicylic acid, and amino acids, including L-arginine and L-cysteine, reduce the toxicity of anticancer drugs towards adenocarcinoma cells (A549). Working with other types of oxides, Sahu et al. [16] demonstrated that ZnO 
and $\mathrm{SiO}_{2}$ nanoparticles possess different cytotoxicity between particle sizes and cell types such as human monocytes (THP-1 cells) and human lung cells (L-132).

Research with gold and silver metallic nanoparticles are also abundant. For example, Ma et al. [17] prepared gold nanoparticles to study how the degradation of corona protein affects cytotoxicity on cells; among the findings of the work, the different rates of enzymatic degradation of the corona stand out, which can lead to differences in the induction of toxicity and production of reactive oxygen species (ROS). Vazquez-Muñoz et al. [18] tested silver nanoparticles on different taxonomical groups to study their effects on different living systems including cancer cell lines. According to the authors, organisms of different complexities are inhibited in vitro at microgram-scale concentrations of $\mathrm{Ag}$ in different forms.

In this work, a new colloidal magnetic poly(vinyl pivalate) dispersion was synthesized via the emulsion polymerization method. Based on the proposed approach, $\mathrm{Fe}_{3} \mathrm{O}_{4}$ magnetic nanoparticles were individually coated by poly(vinyl pivalate) in a controlled way. In order to accomplish a proper magnetic nanoparticle coating, the experimental protocol followed two main singles steps: (i) surface modification of $\mathrm{Fe}_{3} \mathrm{O}_{4}$ nanoparticles with acrylic acid or methacrylic acid to enhance the encapsulation efficiency, as these surface modification agents guarantee chemical linking due to the copolymerization of acrylic acid or methacrylic acid on the $\mathrm{Fe}_{3} \mathrm{O}_{4}$ nanoparticles' surface with vinyl pivalate to form the particles shell; (ii) an emulsion polymerization process using acrylic acid- or methacrylic acid-functionalized $\mathrm{Fe}_{3} \mathrm{O}_{4}$ nanoparticles as a polymerization locus to encapsulate them individually with a controlled thickness of a poly(vinyl pivalate) layer. It is worth bearing in mind that the surface modification of magnetic nanoparticles with polymerizable modification agents avoid the undesirable leaching problems of $\mathrm{Fe}_{3} \mathrm{O}_{4}$ nanoparticles, ultimately ensuring the formation of a magnetic nanodispersion containing individually encapsulated nanoparticles with a high magnetic response.

To provide insight into applications in the biomedical field, the magneto-polymeric materials synthesized in the present work were evaluated in cytotoxicity assays in vitro for fibroblasts, keratinocytes, and human melanoma cells. These materials were also characterized through analytical techniques such as infrared (FTIR), thermogravimetric analyses (TGAs), differential scanning calorimetry (DSC), X-ray powder diffraction (XRD), magnetization measurements (VSMs), transmission electron microscopy (TEM), and temogravimetry. To improve stability and dispersion into the polymer matrices, a surface modification was necessary; this is an essential step for the synthesis of magneto-polymeric materials through emulsion polymerization to guarantee a better compatibilization between vinyl pivalate and magnetic nanoparticles. In this work, this was made using acrylic acid and methacrylic acid to modify the surface of magnetite nanoparticles after the coprecipitation process.

\section{Materials and Methods}

\subsection{Materials}

Distilled water was a reactional media. Gas nitrogen (White Martins Ltda., Rio de Janeiro, Brazil) was used in all reactions to maintain an inert atmosphere. Sodium hydroxide $(\mathrm{NaOH}, 99 \%)$, ferric chloride hexahydrate $\left(\mathrm{FeCl}_{3} \cdot 6 \mathrm{H}_{2} \mathrm{O}, 97 \%\right)$, ferrous sulfate heptahydrate $\left(\mathrm{FeSO}_{4} \cdot 7 \mathrm{H}_{2} \mathrm{O}, 99 \%\right)$, hydrochloric acid $(\mathrm{HCl}, 37 \%)$, acetone $(99.5 \%)$, aluminum sulfate $\left(\mathrm{Al}_{2}\left(\mathrm{SO}_{4}\right)_{3}, 98 \%\right)$, acrylic (VETEC Química Fina Ltda., Rio de Janeiro, Brazil, 99\%), and methacrylic acid (VETEC Química Fina Ltda., Rio de Janeiro, Brazil, 99\%). Vinyl pivalate (stabilized with MEHQ 6-15 ppm, Aldrich, St. Louis, MO, USA, 99\%), hydroquinone (Merck, São Paulo, Brazil, 99\%). All reagents were used as received.

\subsection{Preparation of Magnetite Nanoparticles (MNPs)}

Magnetite nanoparticles $\left(\mathrm{Fe}_{3} \mathrm{O}_{4}\right)$ were produced by the coprecipitation method. $\mathrm{FeSO}_{4} \cdot 7 \mathrm{H}_{2} \mathrm{O}$ and $\mathrm{FeCl}_{3} \cdot 6 \mathrm{H}_{2} \mathrm{O}$ (1:2 molar ratio) were dissolved in $130 \mathrm{~mL}$ hydrochloric solution $\left(0.45 \mathrm{Mol} \cdot \mathrm{L}^{-1}\right)$ under an $\mathrm{N}_{2}$ atmosphere and mechanical stirring for $30 \mathrm{~min}$ in a similar way as described by Neto et al. [19]. The solution was heated to $60^{\circ} \mathrm{C}$ and added 
quickly to a $60{ }^{\circ} \mathrm{C} \mathrm{NaOH}$ solution $\left(1.48 \mathrm{~mol} \cdot \mathrm{L}^{-1}\right)$ previously heated. The $\mathrm{NaOH}$ used in this system, at $\mathrm{pH} 11$, had the role of a precipitating agent. The mixture was allowed to react for $30 \mathrm{~min}$ at $60{ }^{\circ} \mathrm{C}$. The produced nanoparticles were washed several times with distilled water until reaching $\mathrm{pH} 7$ and were separated using a magnet. The freshly obtained nanoparticles were dispersed on hexane and stored in a fridge.

\subsection{Functionalization of Magnetite Nanoparticles}

Initially, $5 \mathrm{~g}$ of dried magnetite nanoparticles were dispersed on $170 \mathrm{~mL}$ of water with magnetic stirring. The mixture was heated to $85{ }^{\circ} \mathrm{C}$ under a nitrogen atmosphere and $5.6 \mathrm{~mL}$ of acrylic acid or methacrylic acid were added by dripping at a rate of $0.5 \mathrm{~mL} / \mathrm{min}$ in order to functionalize the nanoparticle surface. After this, the system was left to react for $30 \mathrm{~min}$ and cooled to room temperature.

The resultant material formed a stable colloidal dispersion after decanting the nanoparticulated system in the reaction flask by magnetic separation with a magnetic bar of neodymium, and nanoparticles were washed with distilled water until the solution reaches $\mathrm{pH}=7$. After this procedure, functionalized nanoparticles (20-25 wt \% related to vinyl pivalate) were washed with acetone to remove residual acrylic or methacrylic acid and then dispersed into vinyl pivalate and stored under a nitrogen atmosphere in the fridge.

\subsection{Synthesis of $\mathrm{Fe}_{3} \mathrm{O}_{4} /$ Poly(vinyl pivalate) Composite Nanoparticles}

Emulsion polymerizations were performed in a glass reactor coupled with a water thermal bath and condenser. First, $12 \mathrm{~g} \cdot \mathrm{L}^{-1}$ sodium dodecyl sulfate (SDS) and $2.5 \mathrm{~g} \cdot \mathrm{L}^{-1}$ potassium persulfate (KPS) solutions were prepared, and then modified surface magnetite nanoparticles (samples of $\mathrm{Fe}_{3} \mathrm{O}_{4} / \mathrm{AA}$ and $\mathrm{Fe}_{3} \mathrm{O}_{4} / \mathrm{MA}$ ) were sonicated for 2 min and dispersed in SDS solution. After, the mixture was placed on the reactor and the KPS solution was added.

The system was heated with mechanical stirring (500 rpm) and a nitrogen atmosphere. When the temperature system reached $80{ }^{\circ} \mathrm{C}$, acrylic acid was added at a rate of $0.1 \mathrm{~mL} \cdot \mathrm{min}^{-1}$ under bubbling of nitrogen gas, which was maintained throughout the reaction, to prevent early oxidation of magnetite nanoparticles caused by factors such as $\mathrm{pH}$, temperature, and radical initiator.

After acrylic acid addition, the system was left on magnetic stirring for 30 min prior to the addition of vinyl pivalate monomer at a $0.25 \mathrm{~mL} / \mathrm{min}$ rate using a solenoid pump (Prominent ${ }^{\circledR}$ Gala series gamma/L PVT 1000, São Paulo, Brazil). When the addition ended, the system was left to react for another $30 \mathrm{~min}$ to guarantee the total consumption of the initiator.

After interrupting the reaction, freshly hydroquinone was added to inhibit further polymerizations, and $10 \mathrm{~mL}$ polymer samples (i.e., AA20NP20 and AM25NP20) of the obtained latex were dried for further analyses. These samples were put in an oven at $60{ }^{\circ} \mathrm{C}$ for $72 \mathrm{~h}$ for removal of volatile species in an amorphous polymer phase. All quantities used in this procedure are listed in Table 1.

Table 1. Recipe for the in situ synthesis of magnetic poly(vinyl pivalate) nanocomposites.

\begin{tabular}{cccc}
\hline Species & Weight $(\mathbf{g})$ & Concentration $\left(\mathbf{g} \cdot \mathbf{L}^{-\mathbf{1}}\right)$ & Volume $(\mathbf{m L})$ \\
\hline Vinyl pivalate & 20 & - & 23 \\
Aqueous phase & - & - & 45 \\
SDS & 0.3 & 12 & 25 \\
KPS & 0.05 & 2.5 & 20 \\
Nanoparticles & $1-4$ & - & - \\
Acrylic acid or & - & - & 2 \\
methacrylic acid & & & \\
\hline
\end{tabular}




\subsection{Materials Characterization}

Fourier transform infrared spectroscopy (FTIR) was performed with a Varian FT/IR-4100 using $\mathrm{KBr}$ pellets to verify the functionalization of nanoparticles and polymeric materials.

Thermogravimetric analysis was performed on a Shimadzu TA-60WS to evaluate the thermal stability of nanocomposites, operating at a $10{ }^{\circ} \mathrm{C} \cdot \mathrm{min}^{-1}$ heating rate and a $50 \mathrm{~mL} \cdot \mathrm{min}^{-1} \mathrm{~N}_{2}$ flow. The amount of material on a platinum crucible was approximately $10 \mathrm{mg}$. Differential scanning calorimetry (DSC) was performed on Shimadzu equipment (DSC-60) operating at a $10^{\circ} \mathrm{C} \cdot \mathrm{min}^{-1}$ heating rate under a $30 \mathrm{~mL} \cdot \mathrm{min}^{-1} \mathrm{~N}_{2}$ flow and temperature range. The amount of material on the closed aluminum crucible was approximately $5 \mathrm{mg}$.

To determine the dimensions and average size of the crystallite, X-ray diffraction measurements were carried out using a Bruker D8 FOCUS diffractometer (Bruker AXS, Inc., Fitchburg, WI, USA) with $\mathrm{CuK} \alpha_{1}(\lambda=1.54059 \AA)$ as a radiation source and an Ni filter with a $\mathrm{CBO}$ monochromator operating at a $35 \mathrm{kV}$ voltage and $15 \mathrm{~mA}$. The sweep range for

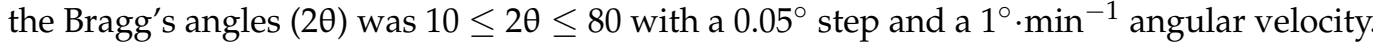

Particle morphology and size distribution of magnetite and composite particles were evaluated by a Jeol model JEM-2100 Transmission electronic microscope (Jeol Ltd., Tokyo, Japan) operated at $200 \mathrm{keV}$ electron beam). The particle size distribution was computed based on the nanoparticle count using the ImageJ program (v.1.53h, https:/ /imagej.nih. gov/ij/ (accessed on 10 November 2021)), and the size distribution graphs were built using Origin software (OriginPro 2021 9.8.0.200, OriginLab Corp., Northampton, MA, USA).

Magnetic measurements were obtained using a commercial superconducting quantum interference device (SQUID) magnetometer (Quantum Design, model MPMS3). Hysteresis cycles were carried out at 5 and $300 \mathrm{~K}$, applying a magnetic field up to $70 \mathrm{kOe}(7 \mathrm{~T})$. Zerofield-cooled (ZFC) and field-cooled (FC) measurements in a low field (30 Oe) were obtained in the temperature range from 5 to $300 \mathrm{~K}$.

\subsection{Cytotoxicity Assays}

Since it is important to know how nanoparticles behave in living organisms, in terms of viability and toxicity against cells, knowing the acceptable levels of materials at the cellular level helps in determining the quantities that can be administered during applications of these materials in living organisms.

In vitro assays were realized using fibroblast and human keratinocyte cell lineages and non-melanoma skin cancer (FIBRO, HaCat, and A431, respectively). All cell lineages cited above were cultivated on DMEM (Dulbecco's modified Eagle's medium). Both were tamponed with sodium bicarbonate and supplemented with $10 \%$ fetal bovine serum (FBS) and $1 \%$ antibiotic $(100 \mathrm{UI} / \mathrm{mL}$ penicillin and $100 \mu \mathrm{g} / \mathrm{mL}$ streptomycin) at $\mathrm{pH} 7.2$.

Cells were kept on cell culture flasks in an incubator at $37^{\circ} \mathrm{C}, 95 \%$ humidified air, and $5 \% \mathrm{CO}_{2}$. All experiments were realized on a $\log$ phase of growth cells. For quantification of viable cells, $40 \mu \mathrm{L}$ of trypan blue dye was added on $10 \mu \mathrm{L}$ of cell suspension. This dye penetrates a cell with an intact plasmatic cell membrane and helps to differentiate viable cells.

After quantification, cells were transferred to culture microplates according to the experiment to be accomplished. Viability cell assays were aimed at analyzing cell death (i.e., FIBRO, HaCat, and A431) for 3 different samples at 24, 48, and $72 \mathrm{~h}$ at various concentrations (i.e., $0.01,0.05,0.1,0.25$, and $0.5 \mathrm{mg} / \mathrm{mL}$ ). Based on the obtained results, the experiments were directed to other in vivo biological assays.

To evaluate cell lineages, the samples were seeded on 96-well plates at concentrations of $5 \times 10^{3}, 3 \times 10^{3}$, and $5 \times 10^{3}$ cells per well on a DMEM medium. After $24 \mathrm{~h}$, the initial medium was replaced with a $200 \mu \mathrm{L}$ culture medium containing different samples at different concentrations (i.e., $0.01,0.05,0.1,0.25,0.5$, and $1.0 \mathrm{mg} / \mathrm{mL}$ ).

Evaluation of cell viability was made using the colorimetric method with 3-(4,5dimethyl-2-thiazolyl)-2,5-diphenyl-2H-tetrazolium bromide) (MTT) as a reduction agent. 
Quantification was conducted by spectrophotometry at a $595 \mathrm{~nm}$ wavelength. The results were obtained based on the average of 3 independent experiments conducted in triplicate.

The MTT assay was the chosen method to evaluate particle cytotoxicity once the compound was reduced to formazan, generated by mitochondrial dehydrogenases that are indicative of cell viability. Thus, these experiments evaluated the cell viability of the lineages used in this study.

\section{Results and Discussion}

To determine the crystalline structure and crystallite size $\left(D_{\mathrm{XRD}}\right)$ of synthesized $\mathrm{Fe}_{3} \mathrm{O}_{4}$, $X$-ray diffraction (XRD) data analysis was performed. Characteristic peaks of nanoparticles at $2 \theta$ were observed at approximately $30^{\circ}, 35.5^{\circ}, 43^{\circ}, 54^{\circ}, 57^{\circ}$, and $63^{\circ}$ (Figure 1 ). These peaks were related to the Miller indexes of (220), (311), (400), (422), (511), and (440), which confirmed the formation of a spinel structure of $\mathrm{Fe}_{3} \mathrm{O}_{4}[20,21]$. In order to estimate the crystallite size, the Debye-Scherrer relation (Equation (1)) was used:

$$
D_{X R D}=\frac{k \cdot \lambda}{\beta \cdot \cos (\theta)}
$$

where $k$ is a constant assumed to be equal to 0.9 (n.b., $k$ values are normally in the range from 0.87 to 1.00$) ; \lambda$ is the $X$-ray wavelength (equal to $0.154059 \mathrm{~nm}, \mathrm{CuK} \alpha_{1}$ radiation); $\theta$ stands for the Bragg diffraction angle, and $\beta$ corresponds to the full width at the half maximum (FWHM) of the Bragg reflections. Using the linewidth of the most intense peak (e.g., associated to the (311) Miller index), an average crystallite size of $8.2 \pm 0.2 \mathrm{~nm}$ was determined.

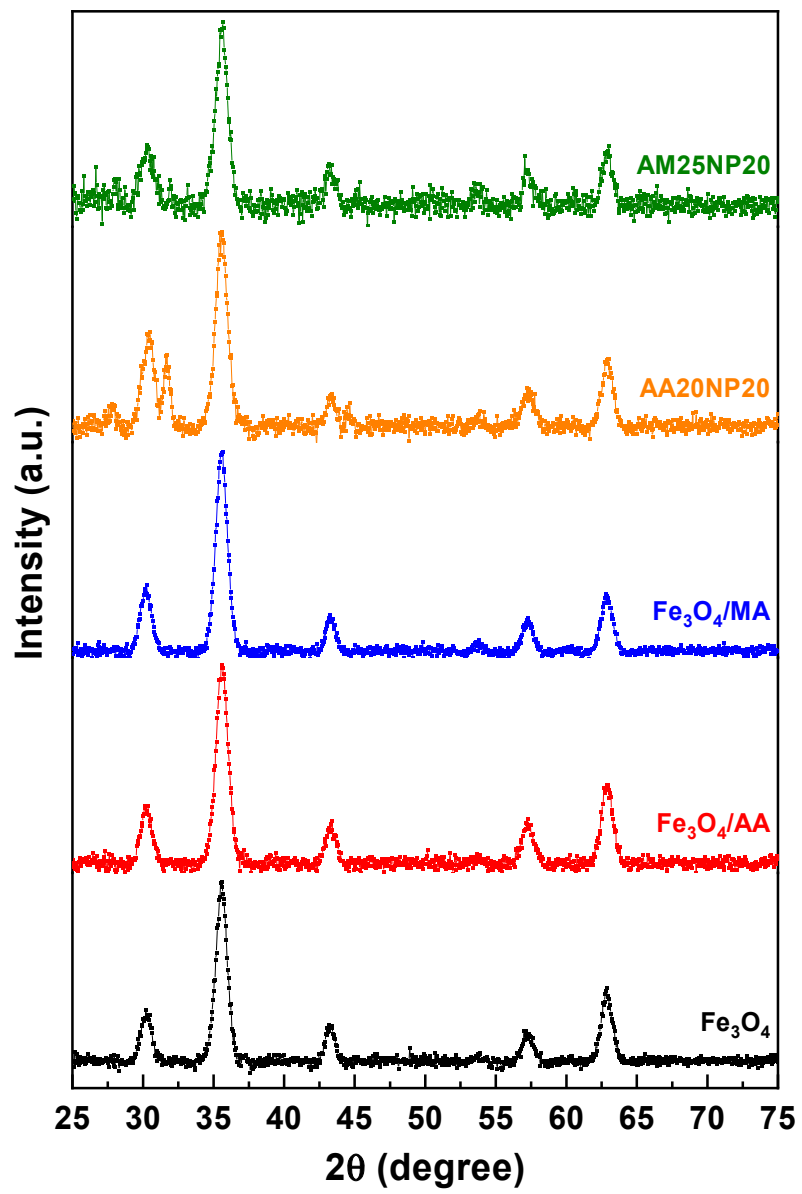

Figure 1. X-ray diffractograms of pure $\mathrm{Fe}_{3} \mathrm{O}_{4}$ nanoparticles $\left(\mathrm{Fe}_{3} \mathrm{O}_{4}\right)$, acrylic acid, and methacrylic acid surface-modified $\mathrm{Fe}_{3} \mathrm{O}_{4}$ nanoparticles and magnetic poly(vinyl pivalate) nanocomposites (i.e., AA20NP20 and AM25NP20). 
There was the large possibility of formation of the maghemite phase next to the magnetite phase, since both phases exhibited similar XRD patterns. The Bragg reflection (440) can provide some clues. According to the literature [22], the position of that reflection peak at $62.8^{\circ}$ (Figure 1 and Table 1) suggests the presence of the maghemite phase or nonstoichiometric magnetite likely at the particle surface.

Once diffraction values are quite similar between functionalized and non-functionalized nanoparticles, the presence of acrylic acid or methacrylic acid did not affect the properties in terms of structure and crystallinity [23]. In this case, the likely presence of the maghemite $\left(\gamma-\mathrm{Fe}_{2} \mathrm{O}_{3}\right)$ phase was also determined, since the diffractograms show the (440) peak at $62.8^{\circ}$. Table 2 shows the characteristic peaks, Miller indexes and crystallite size of pure and functionalized magnetite along with magneto-polymers.

Table 2. Characteristic peaks along with Miller indexes, crystallite size, lattice parameter, and stoichiometry of pure and modified $\mathrm{Fe}_{3} \mathrm{O}_{4}$ magnetic nanoparticles and magnetic poly(vinyl pivalate) nanocomposites.

\begin{tabular}{|c|c|c|c|c|c|c|c|c|c|}
\hline \multirow{2}{*}{$\begin{array}{l}\text { Sample Peaks } \\
(2 \theta)\end{array}$} & \multicolumn{6}{|c|}{ Miller Indexes } & \multirow{2}{*}{$D_{\text {XRD }}(\mathrm{nm})$} & \multirow{2}{*}{$a(\AA)$} & \multirow{2}{*}{$\begin{array}{l}\text { Stoichiometry } \\
\qquad\left(\mathrm{Fe}_{3-\delta} \mathrm{O}_{4}\right)\end{array}$} \\
\hline & $(220)$ & (311) & $(400)$ & $(422)$ & (511) & $(440)$ & & & \\
\hline $\mathrm{Fe}_{3} \mathrm{O}_{4}$ & 30.2 & 35.5 & 43.3 & 54.2 & 57.2 & 62.8 & 8.44 & 8.358 & $\mathrm{Fe}_{2.79} \mathrm{O}_{4}$ \\
\hline $\mathrm{Fe}_{3} \mathrm{O}_{4} / \mathrm{AA}$ & 30.2 & 35.6 & 43.4 & 54.0 & 57.2 & 63.1 & 8.00 & 8.368 & $\mathrm{Fe}_{2.86} \mathrm{O}_{4}$ \\
\hline $\mathrm{Fe}_{3} \mathrm{O}_{4} / \mathrm{MA}$ & 30.2 & 35.6 & 43.3 & 54.0 & 57.2 & 63.1 & 8.29 & 8.347 & $\mathrm{Fe}_{2.71} \mathrm{O}_{4}$ \\
\hline AA20NP20 & 30.4 & 35.5 & 43.3 & 53.7 & 57.3 & 63.1 & 8.07 & 8.357 & $\mathrm{Fe}_{2.79} \mathrm{O}_{4}$ \\
\hline AM25NP20 & 30.3 & 35.6 & 43.3 & 54.0 & 57.2 & 62.9 & 8.04 & 8.346 & $\mathrm{Fe}_{2.71} \mathrm{O}_{4}$ \\
\hline
\end{tabular}

Although magnetite and maghemite exhibited very similar diffraction patterns, crystalline structure and, therefore, cubic spinel type, the lattice parameter $(a)$ provides fundamental insight into the stoichiometry of the magnetite nanoparticles present in the magnetic materials, as magnetite ( $a=8.396 \AA$ ) can be oxidized to maghemite $(a=8.346 \AA)$ [24-26], following a process that may take place throughout material synthesis steps as a result of the oxidation of unstable $\mathrm{Fe}^{2+}$ cations in the inverse-spinel magnetite octahedral site into $\mathrm{Fe}^{3+}$, leading to slight changes in the magnetite stoichiometry $[25,26]$. The lattice parameter $(a)$ of magnetite into the magnetic materials were calculated based on the interplanar distance $\left(d_{h k l}\right)$ associated with the reflection (311) according to Equation (2) [19].

$$
a=d_{h k l} \sqrt{h^{2}+k^{2}+l^{2}}
$$

Partially oxidized magnetite (or non-stoichiometric magnetite) is generally expressed as $\mathrm{Fe}_{3-\delta} \mathrm{O}_{4}$ with $0.00 \leq \delta \leq 0.33$, which can be used to infer deviations from stoichiometric magnetite $\left(\delta=0.00, \mathrm{Fe}_{3} \mathrm{O}_{4}\right)$ to completely oxidized magnetite $\left(\delta=0.33, \gamma-\mathrm{Fe}_{2} \mathrm{O}_{3} @\right.$ $\left.\mathrm{Fe}_{2.67} \mathrm{O}_{4}\right)[25,26]$. Equation (3) provides a linear relationship between the lattice parameter and the $\mathrm{Fe}^{2+} / \mathrm{Fe}^{3+}$ molar ratio $(x)$, whereas Equation (4) correlates the parameter $\delta$ with the $\mathrm{Fe}^{2+} / \mathrm{Fe}^{3+}$ molar ratio $(0.0 \leq x \leq 0.5)[19,27]$.

$$
\begin{gathered}
a=8.34134+0.10512 x \\
x=\frac{\mathrm{Fe}^{2+}}{\mathrm{Fe}^{3+}}=\frac{1-3 \delta}{2+2 \delta}
\end{gathered}
$$

In order to directly evaluate the stoichiometric parameter $(\delta)$ allowing for the establishment of the stoichiometry of the nanoparticles $\left(\mathrm{Fe}_{3-\delta} \mathrm{O}_{4}\right)$ present in the magnetic materials, Equations (3) and (4) were combined, resulting in Equation (5).

$$
\delta=-\frac{8.39390-a}{8.18366-a}
$$


According to results from Equation (5), the stoichiometric parameter $(\delta)$ was in the interval from 0.14 to 0.29 , showing that the precursor magnetite nanoparticles were partially oxidized to maghemite, resulting in the stoichiometry varying from $\mathrm{Fe}_{2.71} \mathrm{O}_{4}$ to $\mathrm{Fe}_{2.86} \mathrm{O}_{4}$ (Table 2) between the magnetite and maghemite phases.

Since biomedical applications are dependent on particle size, the relationship of the critical size and particle size obtained from measurements, such as TEM and XRD, should be noted. In the case of magnetite, the critical size was approximately $20 \mathrm{~nm}$ [28].

$\mathrm{Fe}_{3} \mathrm{O}_{4} /$ poly(vinyl pivalate) nanocomposites were produced by emulsion polymerization to incorporate magnetic nanoparticles in a poly(vinyl pivalate) matrix. The use of acrylic acid or methacrylic acid as a free-radical polymerizable coating to modify the surface of the magnetic nanoparticles combined with emulsion polymerization protocol plays a fundamental role in the proper and individual encapsulation of surface-modified magnetite, leading to the formation of a superparamagnetic material exhibiting an elevated magnetic response with great potential for employment in biomedical applications such as the treatment of tumors by hyperthermia.

The average size $\left(D_{\text {TEM }}\right)$ found for the synthesized pure magnetite particles was $7.0 \pm 1.6 \mathrm{~nm},\left(\mathrm{~N}=338\right.$ particles, sample $\left.\mathrm{Fe}_{3} \mathrm{O}_{4}\right), 6.4 \pm 1.7 \mathrm{~nm}$ for acrylic acid-modified magnetite $\left(N=603\right.$ particles, sample $\left.\mathrm{Fe}_{3} \mathrm{O}_{4} / \mathrm{AA}\right)$, and $5.8 \pm 1.6 \mathrm{~nm}$ for methacrylic acidmodified magnetite $\left(N=718\right.$ particles, sample $\left.\mathrm{Fe}_{3} \mathrm{O}_{4} / \mathrm{MA}\right)$, whereas for the nanocomposites, it was $7.4 \pm 2.2 \mathrm{~nm}(N=316$ particles $)$ for sample AA20NP20 and $7.1 \pm 1.8 \mathrm{~nm}$ $(N=273$ particles) for sample AM25NP20 as shown in Figure 2.
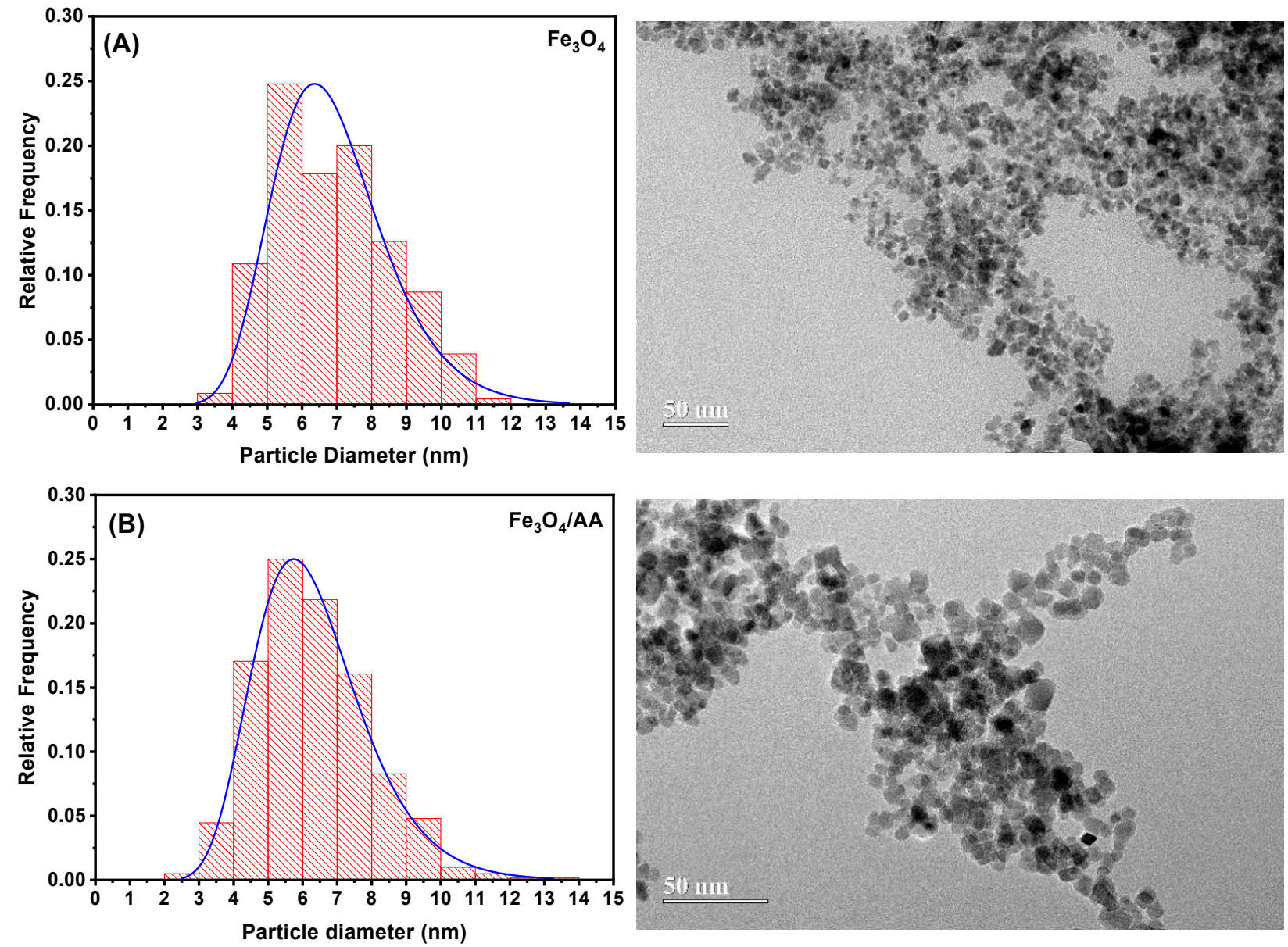

Figure 2. Cont. 

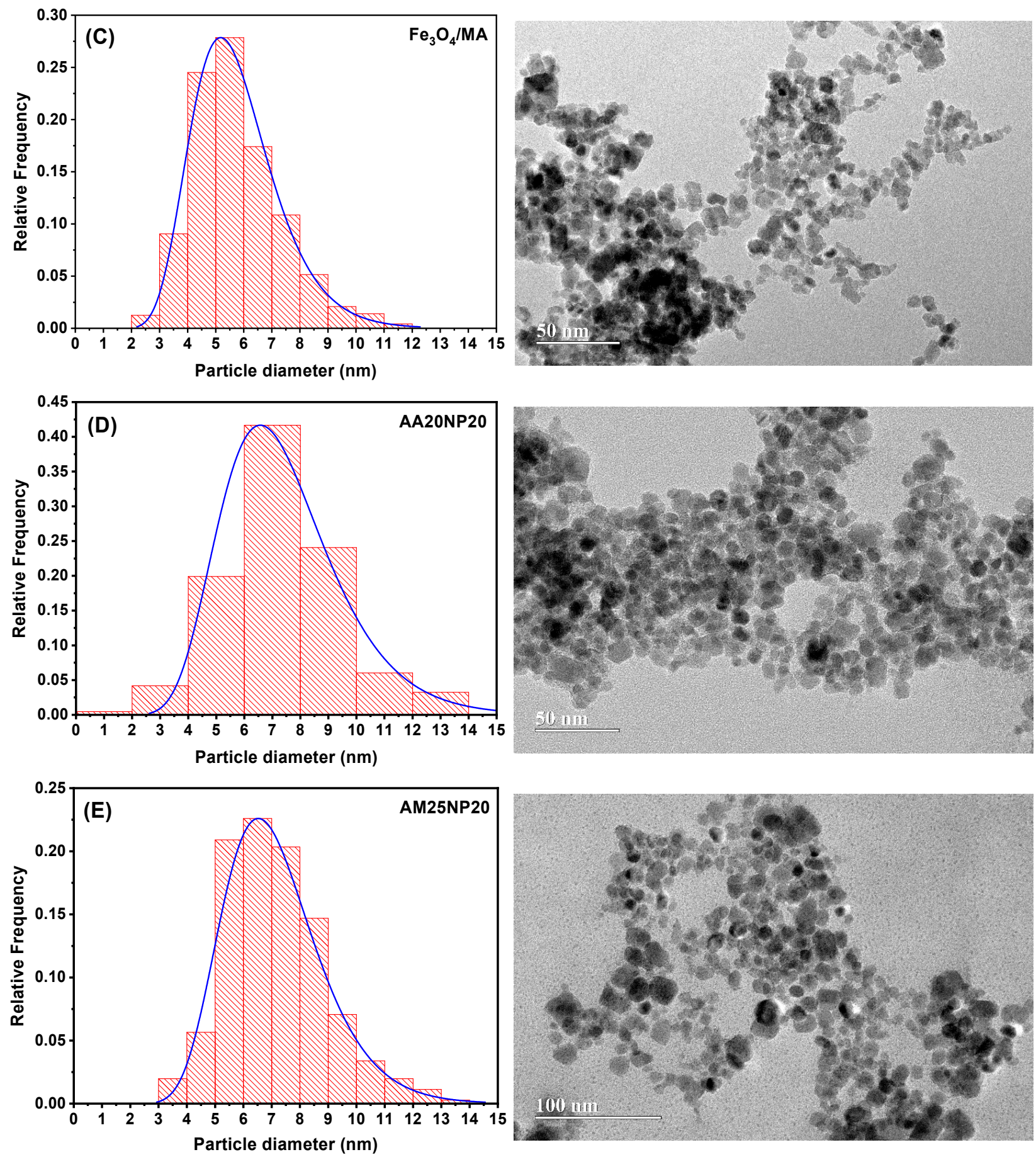

Figure 2. Histograms of the particle size distribution of $\mathrm{Fe}_{3} \mathrm{O}_{4}$ magnetic nanoparticles and micrographs of TEM analysis: (A) non-modified $\mathrm{Fe}_{3} \mathrm{O}_{4}$; (B) surface-modified $\mathrm{Fe}_{3} \mathrm{O}_{4}$ with acrylic acid; (C) surface-modified $\mathrm{Fe}_{3} \mathrm{O}_{4}$ with methacrylic acid; (D) magnetic poly(vinyl pivalate) containing $\mathrm{Fe}_{3} \mathrm{O}_{4}$ modified with acrylic acid (AA20NP20); (E) magnetic poly(vinyl pivalate) containing $\mathrm{Fe}_{3} \mathrm{O}_{4}$ modified with methacrylic acid (AM25NP20). The continuous blue line refers to lognormal distribution.

The smaller values of $D_{\text {TEM }}$ determined for $\mathrm{Fe}_{3} \mathrm{O}_{4}$ modified with carboxylic acids may be attributed to a possible dissolution of the $\mathrm{Fe}_{3} \mathrm{O}_{4}$ magnetic nanoparticles in an acidic medium. It is important to bear in mind that the dissociation of magnetite can take place at $\mathrm{pH}$ values of approximately three. For this reason, it is plausible to assume that both acrylic acid ( $\mathrm{pKa}=4.25$ ) and methacrylic acid ( $\mathrm{pKa}=4.66)$ used in the process may be responsible for this size difference [29-31]. Despite this, the experimental procedure 
adopted for functionalization does not significantly modify the size and morphology of the starting material.

The slight differences observed in the value obtained from TEM (average size, $D_{\text {TEM }}$ ) and XRD (crystallite size, $D_{\mathrm{XRD}}$ ) measurements were consistent with the characteristic of each analytical technique. The XRD data showed a statistical representation of crystal characteristics at the nanoscale with the $D_{\text {XRD }}$ estimated based on the information from the (311) Miller index, whereas the TEM showed an analysis of the size distribution of particles for a specific population [32]. It is worth noticing that for both magnetic nanocomposites (samples AA20NP20 and AM25NP20), DTEM increased in comparison to the modified magnetite nanoparticles (samples $\mathrm{Fe}_{3} \mathrm{O}_{4} / \mathrm{AA}$ and $\mathrm{Fe}_{3} \mathrm{O}_{4} / \mathrm{MA}$ ), which clearly indicates the presence of the thermoplastic matrix of poly(vinyl pivalate) on the surface of the nanoparticles.

Figure 3 shows the FTIR spectrum of pure magnetite and functionalized nanoparticles. Modified nanoparticles were characterized by the appearance of new peaks and bands. For the bands at $3400-3430 \mathrm{~cm}^{-1}\left(\mathrm{O}-\mathrm{H}\right.$ stretching), $2913 \mathrm{~cm}^{-1}$, and $2840 \mathrm{~cm}^{-1}\left(\mathrm{CH}_{2}\right)$, the peaks were characteristic of modification of nanoparticles with acrylic acid [33-35]; $1628 \mathrm{~cm}^{-1}\left(\mathrm{COO}^{-}\right.$stretching) indicates surface modification with methacrylic acid. The peak at $576 \mathrm{~cm}^{-1}$ characterized $\mathrm{Fe}-\mathrm{O}$ stretching on the octahedral site [21]. Peaks on $1453 \mathrm{~cm}^{-1}, 1214 \mathrm{~cm}^{-1}, 1070 \mathrm{~cm}^{-1}$ (C-O stretching), and $974 \mathrm{~cm}^{-1}$ ( $\mathrm{C}=\mathrm{CH}$ bending) were characteristic of poly(vinyl pivalate) and indicate the occurrence of polymerization.

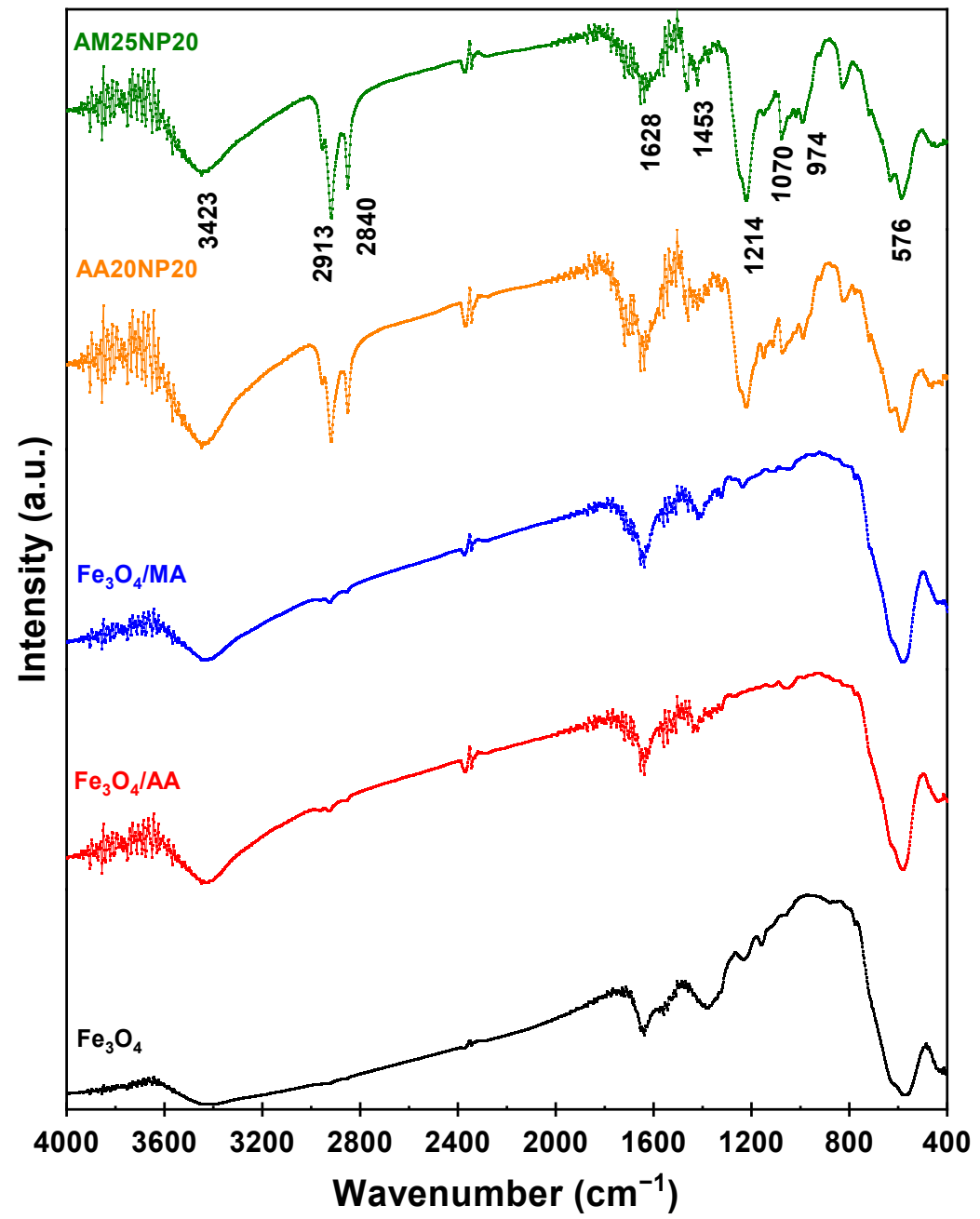

Figure 3. FTIR measurements of pure $\mathrm{Fe}_{3} \mathrm{O}_{4}$ nanoparticles, acrylic acid-modified $\mathrm{Fe}_{3} \mathrm{O}_{4}$, methacrylic acid-functionalized $\mathrm{Fe}_{3} \mathrm{O}_{4}$ nanoparticles, and magnetic polymer nanocomposites (AM25NP20 and AA20NP20). 
Thermal stability of magneto-polymers synthesized and the effect of $\mathrm{Fe}_{3} \mathrm{O}_{4}$ incorporated were investigated by TGA. Two samples were chosen: AA20NP20, where $20 \%$ of magnetite nanoparticles, regarding the monomeric phase, were protected with $20 \%$ of acrylic acid. The second sample, AM25NP20, went through the same process with $25 \%$ of methacrylic acid instead of acrylic acid. The weight losses of 75\% for AA20NP20 and $80 \%$ for AM25NP20 illustrate the amount of organic material attached to the nanoparticle surface as shown in Figure 4A,B.
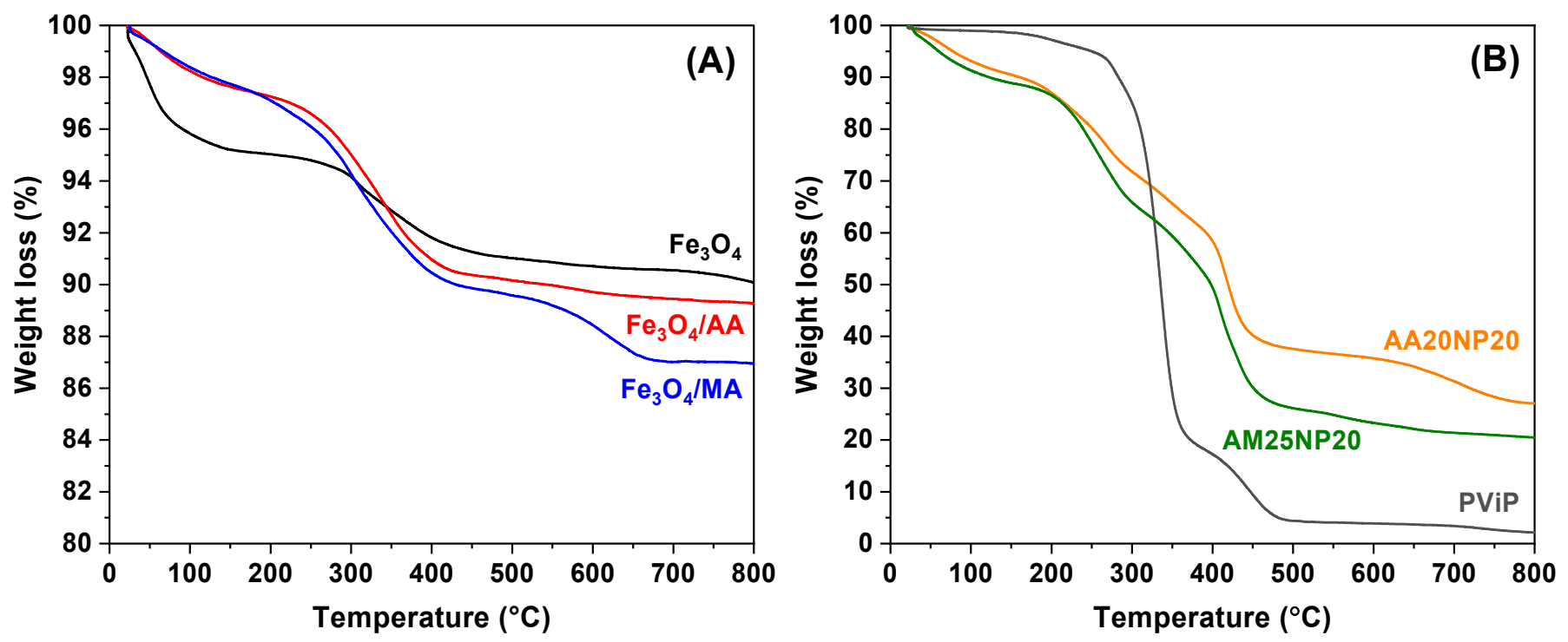

Figure 4. Thermogravimetry analysis: (A) pure $\left(\mathrm{Fe}_{3} \mathrm{O}_{4}\right)^{-}$, acrylic acid $\left(\mathrm{Fe}_{3} \mathrm{O}_{4} / \mathrm{AA}\right)$-, and methacrylic acid $\left(\mathrm{Fe}_{3} \mathrm{O}_{4} / \mathrm{AM}\right)$-functionalized $\mathrm{Fe}_{3} \mathrm{O}_{4}$; (B) magneto-polymers (i.e., AM25NP20 and AA20NP20) and poly(vinyl pivalate) (PViP).

To investigate the effect of magnetite on the thermal degradation of synthesized magneto-polymeric materials, the thermograms of magneto-polymers, shown in Figure 4, were compared with a blank sample. Evaluations of weight losses relative to temperature increases were made on $25 \%\left(\mathrm{Td}_{25}\right), 50 \%\left(\mathrm{Td}_{50}\right)$, and residue at $800{ }^{\circ} \mathrm{C}$ as shown in Table 3 . An increase in the degradation temperature related to the increase in magnetite content on the nanocomposites was observed. This effect suggests that interactions between nanoparticles and polymeric chains may interfere with the thermal degradation of magnetic nanocomposites by elevating their decomposition temperatures, as inorganic compounds, such as iron oxides, generally do not conduct energy quite well due to the presence of moisture and other surface alterations of the compounds at the micro and nanoscales [36].

Table 3. Stability of the magnetic nanocomposites: residual material after calcination and decomposition temperatures.

\begin{tabular}{ccccc}
\hline Sample & MNPs $(\mathbf{w t} \%)$ & $\mathbf{T d}_{\mathbf{2 5}}\left({ }^{\circ} \mathbf{C}\right)$ & $\mathbf{T d}_{\mathbf{5 0}}\left({ }^{\circ} \mathbf{C}\right)$ & Residue at $\mathbf{8 0 0}{ }^{\circ} \mathbf{C}(\mathbf{w t} \mathbf{\%})$ \\
\hline $\mathrm{PViP}$ & 0 & 317 & 336 & 2.2 \\
$\mathrm{Fe}_{3} \mathrm{O}_{4}$ & 100 & - & - & 90.0 \\
$\mathrm{Fe}_{3} \mathrm{O}_{4} / \mathrm{AA}$ & 100 & - & - & 89.3 \\
$\mathrm{Fe}_{3} \mathrm{O}_{4} / \mathrm{MA}^{\mathrm{a}}$ & 100 & - & - & 87.0 \\
$\mathrm{AA20NP20}$ & 20 & 277 & 421 & 27.0 \\
$\mathrm{AM} 25 \mathrm{NP20}$ & 25 & 258 & 398 & 20.0 \\
\hline a Related to the total amount of magnetite $(5 \mathrm{~g})$ dispersed in water $(170 \mathrm{~mL})$ together with $5.6 \mathrm{~mL}$ of carboxylic acid.
\end{tabular}

Once methacrylic acid has a branched chain and a higher molecular weight compared to acrylic acid, it is possible to attribute the highest degradation temperature value to AA20NP20 due to the characteristics of the acids used, since methacrylic acid has a larger volume, which causes a steric hindrance on the surface of the magnetic nanoparticle, thus causing a smaller number of methacrylic groups attached to the surface of the material [37]. 
Additionally, the DSC technique was used to evaluate the glass transition temperature $\left(T_{\mathrm{g}}\right)$ of the magneto-polymeric materials, showing a $T_{\mathrm{g}}$ of $63^{\circ} \mathrm{C}$ for AM25NP20, $62{ }^{\circ} \mathrm{C}$ for AA20NP20, and $65^{\circ} \mathrm{C}$ for poly(vinyl pivalate) (PViP), which indicates that the incorporation of magnetic nanoparticles did not affect the final magneto-polymeric material in comparison to bare poly(vinyl pivalate).

The magnetic properties of the nanocomposites were evaluated through magnetization measurements. In Figure 5, the hysteresis curves of the magnetic materials are shown. The obtained saturation magnetization values at $5 \mathrm{~K}$ for the pure and modified magnetic nanoparticles (samples $\mathrm{Fe}_{3} \mathrm{O}_{4} / \mathrm{AA}$ and $\mathrm{Fe}_{3} \mathrm{O}_{4} / \mathrm{MA}$ ) were in the range from 75 to $81 \mathrm{emu} / \mathrm{g}$, being larger for the $\mathrm{Fe}_{3} \mathrm{O}_{4} / \mathrm{MA}$. The observed magnetization values for synthesized pure nanoparticles were smaller than the value for bulk magnetite. It can probably be attributed to (i) oxidation of magnetite to maghemite during the synthesis stage, mainly at the particle surface; (ii) size effects that cause a reduction in the saturation magnetization. According to the former explanation, the polymer presence seemed to preserve the oxidation process, and it was better for the $\mathrm{Fe}_{3} \mathrm{O}_{4} /$ MA sample [21].
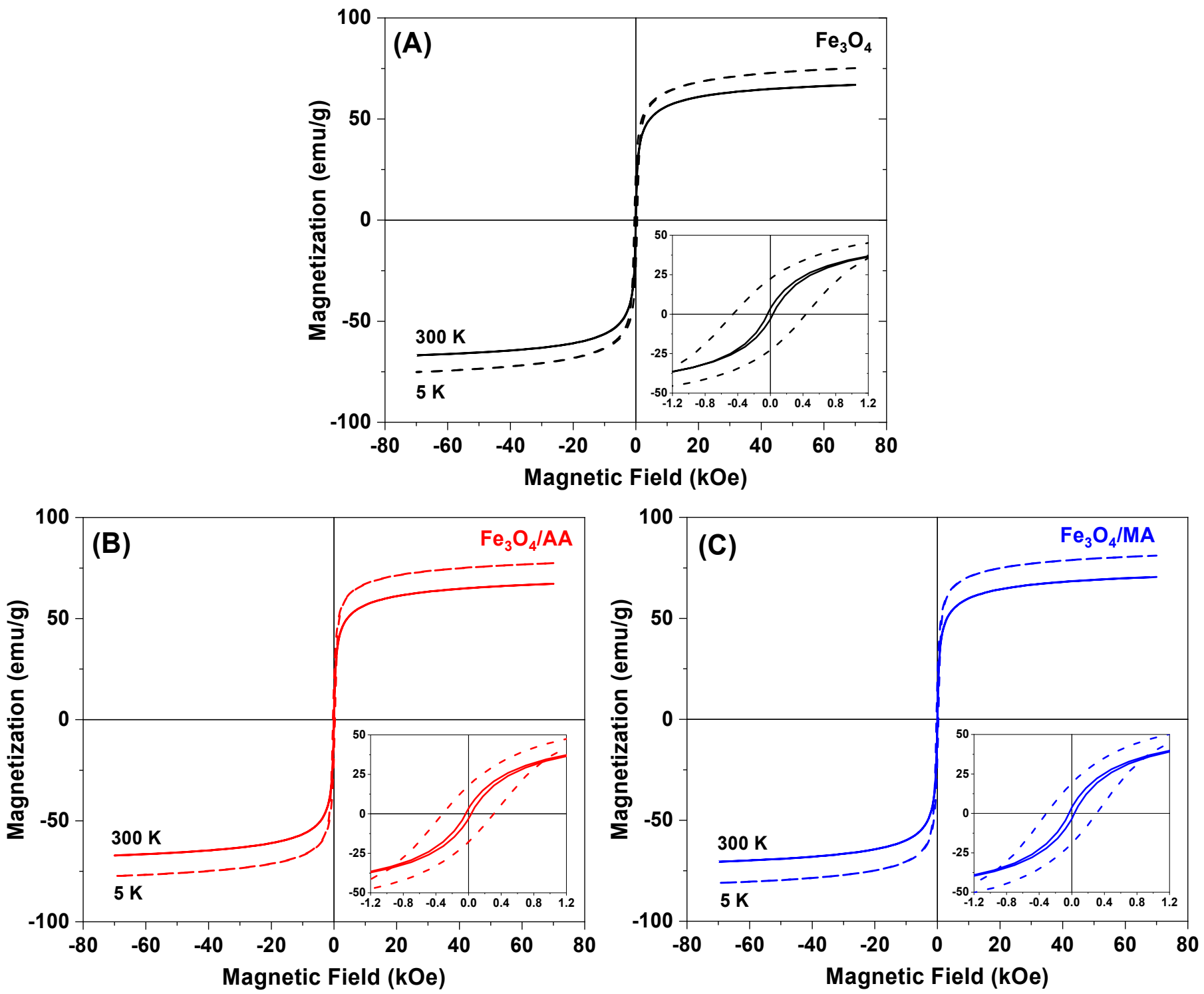

Figure 5. Cont. 

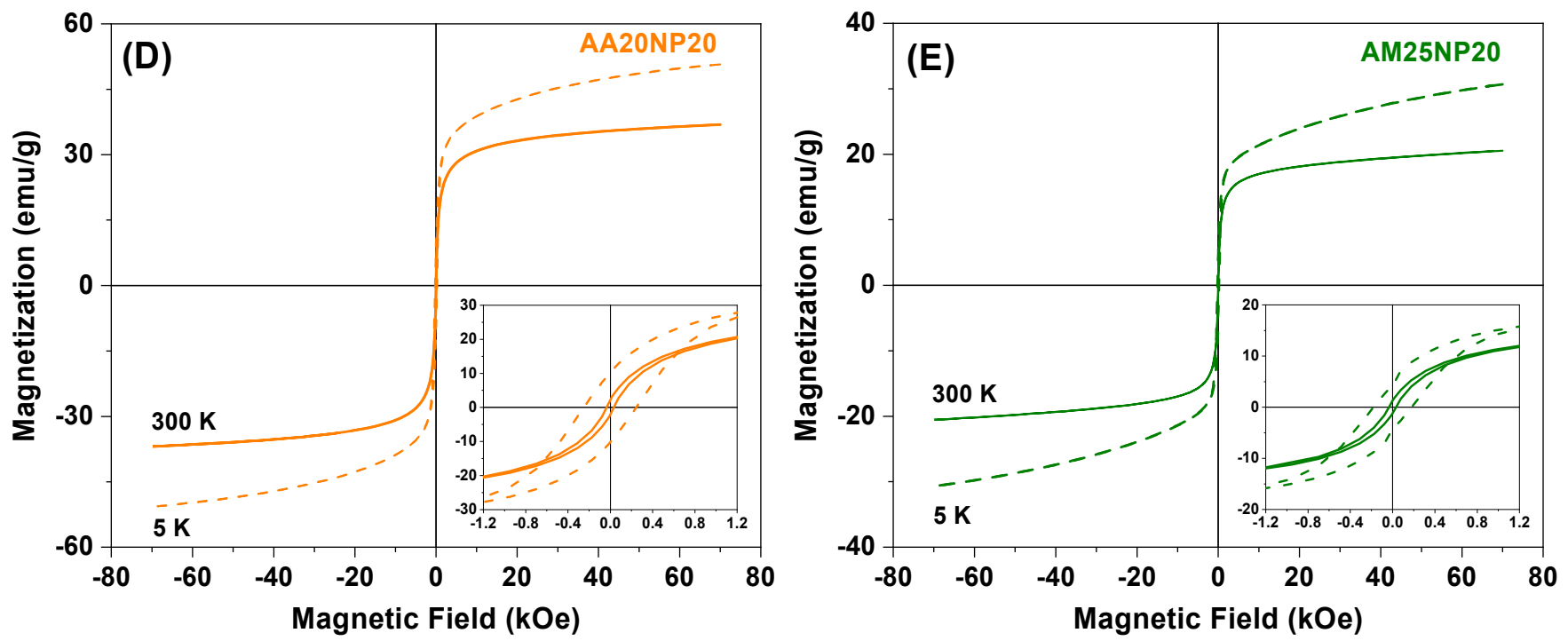

Figure 5. Magnetization curve of (A) non-modified $\mathrm{Fe}_{3} \mathrm{O}_{4} ;(\mathbf{B})$ surface-modified $\mathrm{Fe}_{3} \mathrm{O}_{4}$ with acrylic acid; (C) surface-modified $\mathrm{Fe}_{3} \mathrm{O}_{4}$ with methacrylic acid; (D) magnetic poly(vinyl pivalate) containing $\mathrm{Fe}_{3} \mathrm{O}_{4}$ modified with acrylic acid (AA20NP20); (E) magnetic poly(vinyl pivalate) containing $\mathrm{Fe}_{3} \mathrm{O}_{4}$ modified with methacrylic acid (AM25NP20). The dashed line refers to the temperature of $5 \mathrm{~K}$ and the continuous line to $300 \mathrm{~K}$.

The coercivity near to zero obtained from the $\mathrm{M}$ vs. $\mathrm{H}$ curves at 5 and $300 \mathrm{~K}$ suggests that the particles were in a superparamagnetic state $[38,39]$. At $5 \mathrm{~K}$, a slight increase in the $H_{\mathrm{c}}$ values was observed, because the blocking temperature of magnetite nanoparticles can be above $5 \mathrm{~K}$ [26]. Similar results were obtained for the acrylic- and methacrylic acid-functionalized nanoparticles as can be seen in Figure 5 and Table 4. As mentioned above, an increase in the $M_{\mathrm{S}}$ value for the magnetite particles functionalized with acrylic or methacrylic acid in relation to the pure magnetite particles was observed (Table 2). This effect was linked to the reduction in particle size and the formation of a surface layer with zero magnetization (dead layer) in the pure magnetite particles. The presence of an organic covering, through the functionalization of the particles, helps to reorganize the surface interactions in the crystal, which generates an increase in the saturation magnetization [40].

Table 4. Magnetic properties of the pure and modified $\mathrm{Fe}_{3} \mathrm{O}_{4}$ and magnetic polymers.

\begin{tabular}{|c|c|c|c|c|c|c|c|}
\hline \multirow{2}{*}{ Sample } & \multicolumn{2}{|c|}{$M_{\mathrm{s}}(\mathrm{emu} / \mathrm{g})$} & \multicolumn{2}{|c|}{$H_{\mathrm{c}}(\mathrm{kOe})$} & \multicolumn{2}{|c|}{$M_{\mathrm{r}}(\mathrm{emu} / \mathrm{g})$} & \multirow{2}{*}{$T_{\mathrm{B}}(\mathrm{K})$} \\
\hline & $5 \mathrm{~K}$ & $300 \mathrm{~K}$ & $5 \mathrm{~K}$ & $300 \mathrm{~K}$ & $5 \mathrm{~K}$ & $300 \mathrm{~K}$ & \\
\hline $\mathrm{Fe}_{3} \mathrm{O}_{4}$ & 75.51 & 67.85 & 0.4266 & 0.0042 & 22.41 & 3.50 & 192 \\
\hline $\mathrm{Fe}_{3} \mathrm{O}_{4} / \mathrm{AA}$ & 78.43 & 68.30 & 0.2882 & 0.0053 & 17.86 & 3.33 & 206 \\
\hline $\mathrm{Fe}_{3} \mathrm{O}_{4} / \mathrm{MA}$ & 80.81 & 71.70 & 0.2829 & 0.0047 & 19.09 & 3.66 & 229 \\
\hline AA20NP20 & 50.68 & 36.92 & 0.2214 & 0.0054 & 10.22 & 2.23 & 144 \\
\hline AM25NP20 & 30.68 & 20.59 & 0.1515 & 0.0048 & 4.35 & 1.29 & 146 \\
\hline
\end{tabular}

Regarding the nanocomposites, a decay in the value of magnetization was observed when methacrylic acid (sample AM25NP20) was used in place of acrylic acid (sample AA20NP20) for the surface protection of nanoparticles before polymerization. This observation can be explained by superficial changes in the crystal generated during the functionalization process by the organic cover [41].

Since the carboxylic acids used in the functionalization bind via oxygen from the carboxyl group to the surface of the nanoparticles, this generates a chemical environment similar to that of the macroscopic crystalline magnetite [3,42], since the modification caused by these bonds modifies the surface structure of the spins. The consequences of this are 
due to the role of the ligand groups in the ability to donate electrons, strengthening the bond and density of the functionalization layer. This also allows for the adjustment of $M_{\mathrm{s}}$ and control of the interactions between particles and morphological and structural properties [40,42].

Other important features were obtained from the FC/ZFC curves that can be used to study the thermal relaxation of magnetic nanoparticles. As observed, the field-cooling FC and zero-field-cooling ZFC curves showed irreversible features, depending on the studied sample. The ZFC curves showed an increasing trend as the temperature increased, until reaching a maximum point, which was assigned to the blocking temperature $\left(T_{\mathrm{B}}\right)$. After this point, the ZFC curve showed a decreasing trend as shown in Figure 6.
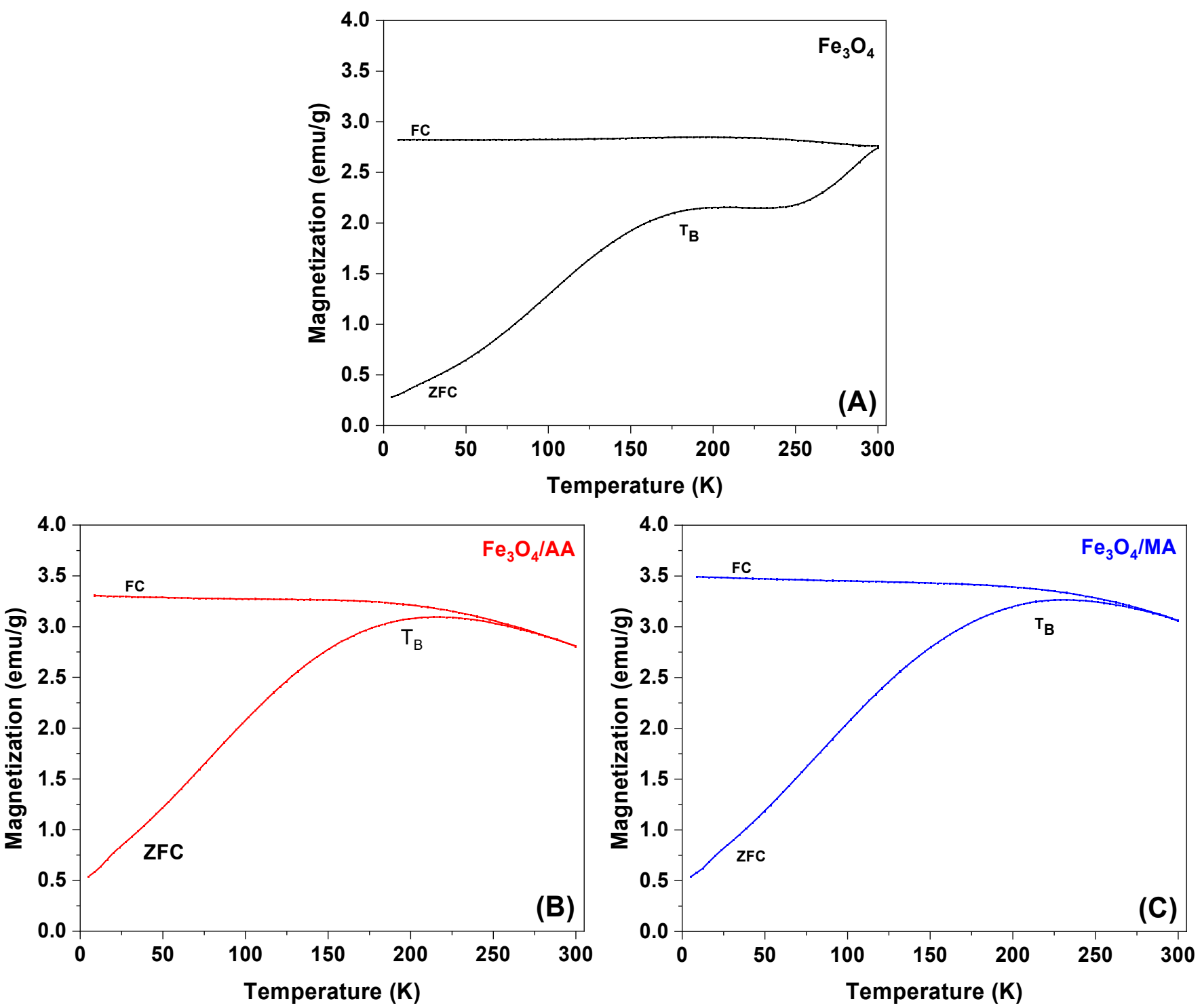

Figure 6. Cont. 

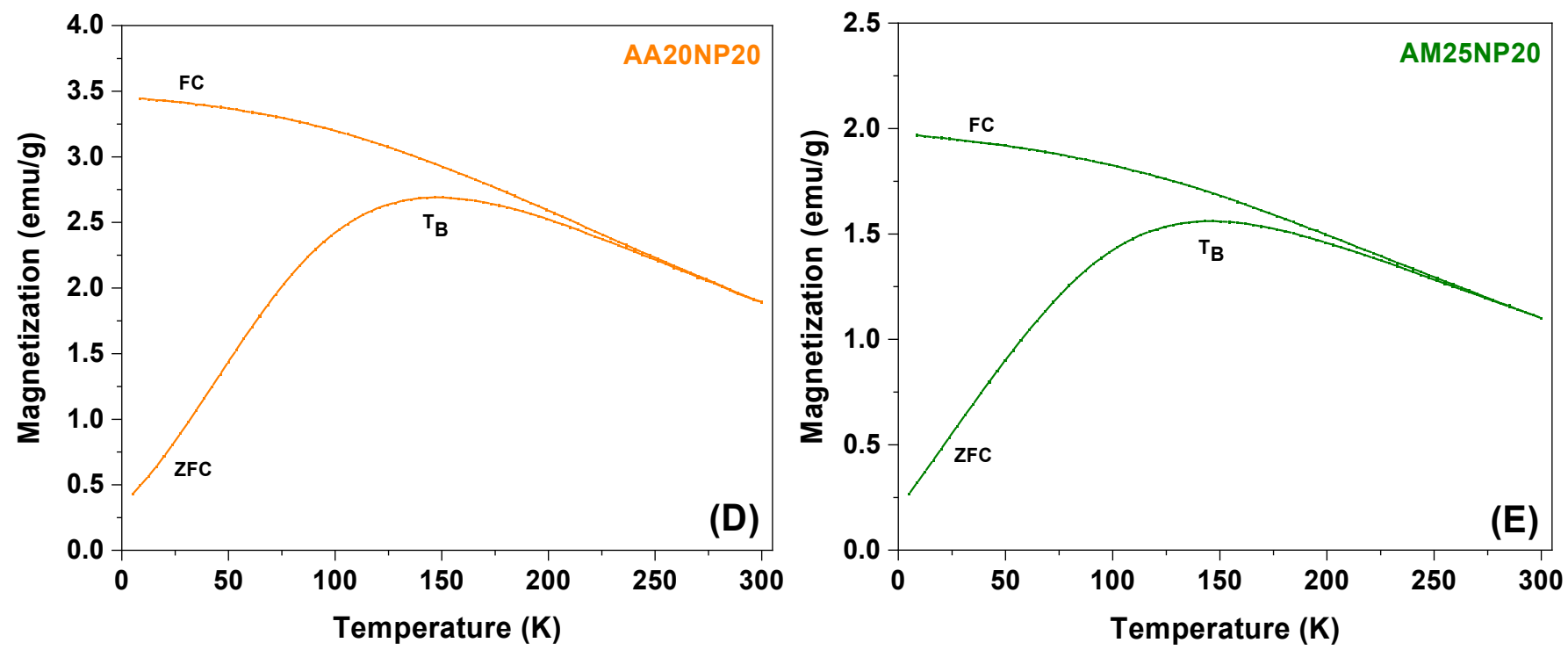

Figure 6. $\mathrm{FC} / \mathrm{ZFC}$ of (A) non-modified $\mathrm{Fe}_{3} \mathrm{O}_{4}$; (B) surface-modified $\mathrm{Fe}_{3} \mathrm{O}_{4}$ with acrylic acid; (C) surface-modified $\mathrm{Fe}_{3} \mathrm{O}_{4}$ with methacrylic acid; (D) magnetic poly(vinyl pivalate) containing $\mathrm{Fe}_{3} \mathrm{O}_{4}$ modified with acrylic acid (AA20NP20); (E) magnetic poly(vinyl pivalate) containing $\mathrm{Fe}_{3} \mathrm{O}_{4}$ modified with methacrylic acid (AM25NP20).

It is well known that the blocking temperature $\left(T_{\mathrm{B}}\right)$ separates the blocking states, at low temperatures, from the relaxed states, at high temperatures. This means that at low temperatures, the thermal energy becomes smaller with respect to the magnetic energy and the magnetic moments of the particles are blocked. At high temperatures, above $T_{\mathrm{B}}$, the thermal energy is higher than the magnetic energy and the system shows a superparamagnetic behavior. As observed in Figure 6, the ZFC curve for pure magnetite shows a broad maximum, and it keeps growing with the temperature. Those features suggest the presence of the bimodal distribution of blocking temperatures. The broad maximum centered at $192 \mathrm{~K}$ seemed to correspond to weakly interacting nanoparticles, meanwhile the increasing trend above that maximum suggests the presence of strongly interacting particles. This scenario seems to be modified in samples $\mathrm{Fe}_{3} \mathrm{O}_{4} / \mathrm{AA}$ and $\mathrm{Fe}_{3} \mathrm{O}_{4} / \mathrm{MA}$. As observed, there was only a maximum for both samples in the ZFC curves, with the blocking temperature nearly at $\sim 206 \mathrm{~K}$ for sample $\mathrm{Fe}_{3} \mathrm{O}_{4} / \mathrm{AA}$, with a little shift to $\sim 229 \mathrm{~K}$ for sample $\mathrm{Fe}_{3} \mathrm{O}_{4} / \mathrm{MA}$, which can be related to the strengthening of the particle-particle interaction. However, after the polymerization, the blocking temperature shifted to lower temperatures, nearly $\sim 140-150 \mathrm{~K}$ for both samples. This shift suggests that the particle-particle interactions weakened after the polymerization, which can be related to the presence of polymeric groups among magnetic particles leading to larger distances among them and, therefore, weak magnetic interactions.

In vitro tests are important in order to determine the level of toxicity of materials in organisms. In the case of nanoparticles, this becomes important since some of the characteristics of these materials can cause unexpected intoxications. A parameter used to verify the low toxicity capacity is cell viability. High values of cell viability indicate low toxicities.

\subsection{FIBRO Lineage Cell Viability}

The obtained results showed that the FIBRO lineage during a $24 \mathrm{~h}$ interval diminished $60 \%$ of the cell viability for sample 1 (PViP) at all concentrations; sample 2 (AA20NP20) was reduced by $30 \%$ from initial concentrations and $50 \%$ at $1.0 \mathrm{mg} / \mathrm{mL}$ concentration. For sample 3 (AM25NP20), only at a $0.05 \mathrm{mg} / \mathrm{mL}$ concentration was the reduction significant, up to $60 \%$ (Figure 7 ). 


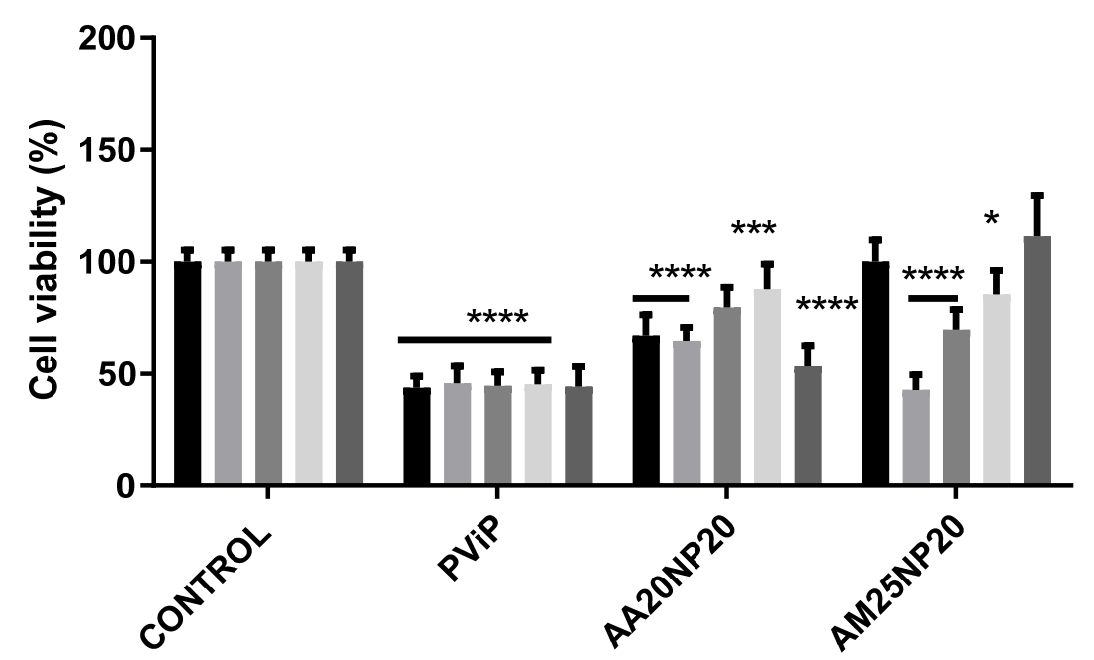

$0.01 \mathrm{mg} / \mathrm{mL}$

$0.05 \mathrm{mg} / \mathrm{mL}$

$0.1 \mathrm{mg} / \mathrm{mL}$

$0.25 \mathrm{mg} / \mathrm{mL}$

$0.5 \mathrm{mg} / \mathrm{mL}$

(A)

$48 h$

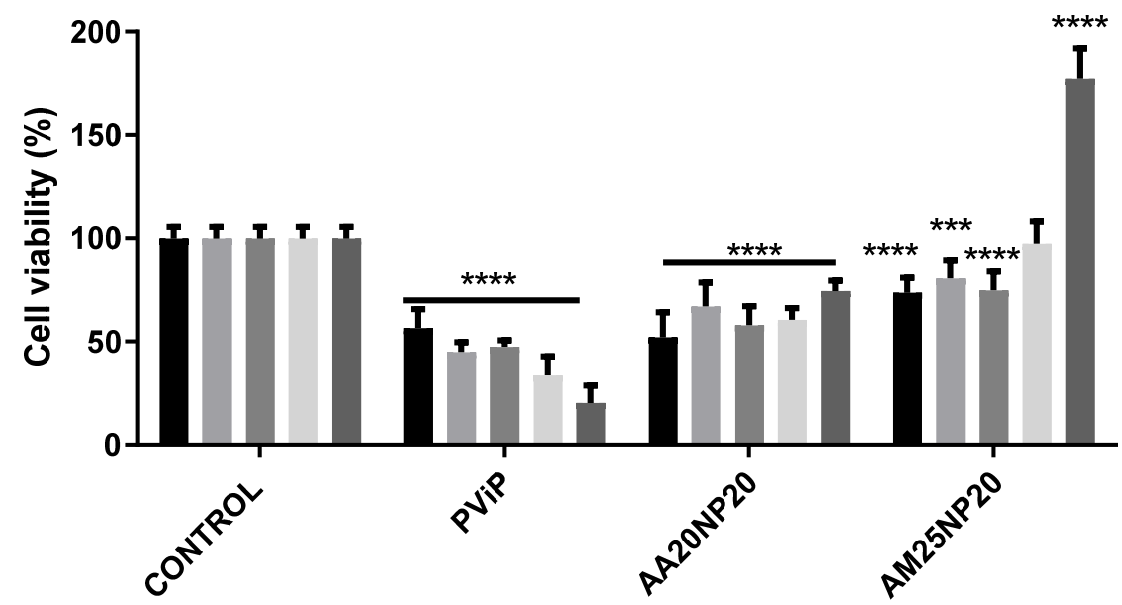

- $0.01 \mathrm{mg} / \mathrm{mL}$

$0.05 \mathrm{mg} / \mathrm{mL}$

- $0.1 \mathrm{mg} / \mathrm{mL}$

$0.25 \mathrm{mg} / \mathrm{mL}$

$0.5 \mathrm{mg} / \mathrm{mL}$

(B)

\section{$72 \mathrm{~h}$}

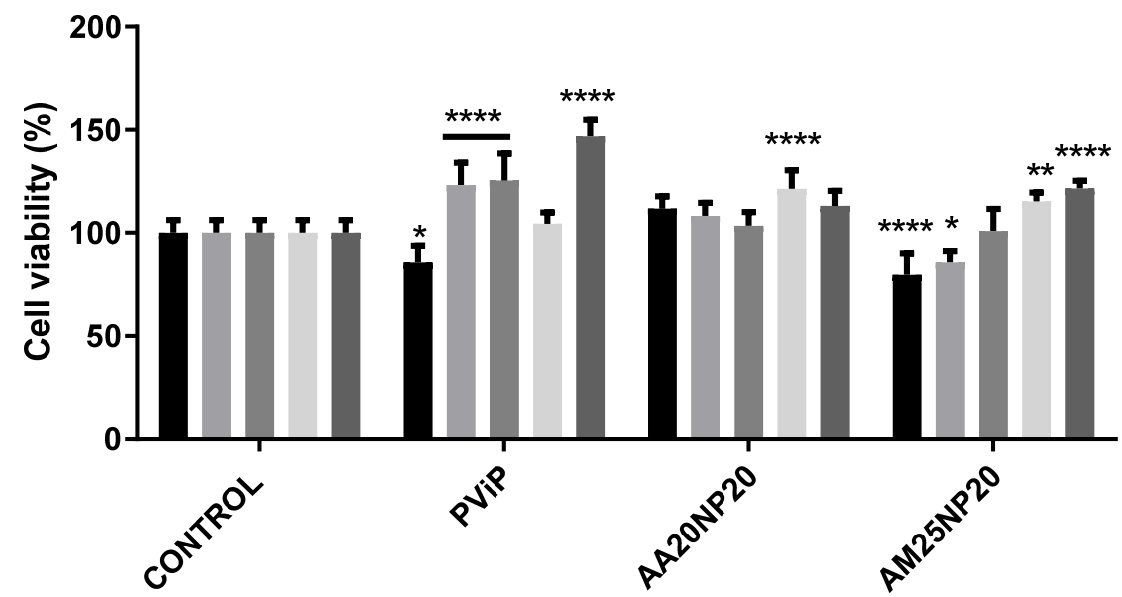

$0.01 \mathrm{mg} / \mathrm{mL}$

$0.05 \mathrm{mg} / \mathrm{mL}$

$0.1 \mathrm{mg} / \mathrm{mL}$

$0.25 \mathrm{mg} / \mathrm{mL}$

$0.5 \mathrm{mg} / \mathrm{mL}$

(C)

Figure 7. Evaluation of the cytotoxic activity of the polymer samples on fibroblast cells after (A) 24, (B) 48 , and (C) $72 \mathrm{~h}$ exposure in the particle concentrations of $0.01,0.05,0.1,0.25$, and $0.5 \mathrm{mg} / \mathrm{mL}$. Asterisks are related to different confidence intervals associated with statistical significance: * $95 \%$ with $p \leq 0.05, * * 99 \%$ with $p \leq 0.01,{ }^{* * *} 99.9 \%$ with $p \leq 0.001$, and ${ }^{* * * *} 99.99 \%$ with $p \leq 0.0001$. 
At $48 \mathrm{~h}$ exposure time for the FIBRO lineage, the results were significant for sample 1, where cytotoxicity was up $80 \%$ with a reduction in viability for $0.5 \mathrm{mg} / \mathrm{mL}$. For other concentrations, the percentage reduction varied $50-70 \%$.

For sample 2, there was a variation of $30-50 \%$ of viability for all concentrations analyzed. Sample 3 suffered a $20-30 \%$ reduction for all concentrations except $0.5 \mathrm{mg} / \mathrm{mL}$, where an increase in viability was observed.

After $72 \mathrm{~h}$ of exposure, for the FIBRO lineage, samples 1 and 2 (PViP and AA20NP20) did not show a reduction for any of the studied concentrations. Sample 3 suffered a 20\% reduction, considered not biologically significant according to the literature for this lineage.

\subsection{HaCaT lineage Cell Viability}

The HaCaT lineage was inserted into the context of this study with the purpose of comparing it with the FIBRO lineage to assess toxicity and, based on these results, the material to be analyzed could be inserted into cosmetics or drugs, since it is human cell lineages such as FIBRO (a fibroblast) and HaCaT (a normal keratinocyte). Both, when combined, corroborated for a more detailed evaluation of cytotoxicity in an in vitro test as well as a comparison with the non-melanoma skin cancer tumor line also used in this study (A431).

Figure 8 shows the results after $24 \mathrm{~h}$ of treatment exposure. It is possible to observe that in sample 1 (PViP), there was a $40 \%$ decrease for all concentrations, and sample 2 (AA20NP20) decreased $40 \%$ in the initial concentrations, $20 \%$ in the intermediate, and a cell increase, that is, proliferation in the greater concentration. For sample 3 (AM25NP20), the decrease in cell viability was almost $40 \%$ for all concentrations.

During a $48 \mathrm{~h}$ time exposure, it was possible to evaluate that in sample 1, there was only a $35 \%$ reduction in the $0.25 \mathrm{mg} / \mathrm{mL}$ concentration; for sample 2 , there was no significant reduction; for sample 3 at initial concentrations, no significant reduction occurred, presenting only a $40 \%$ reduction in cell viability at a greater concentration.

For $72 \mathrm{~h}$ treatment of the HaCat strain, there was observed a toxicity of $30-55 \%$ in sample 1 in the analyzed concentrations; for sample 2, the reduction was only $40 \%$; in sample 3, only the concentration of $0.05 \mathrm{mg} / \mathrm{mL}$ showed a $50 \%$ reduction.

\section{4h}

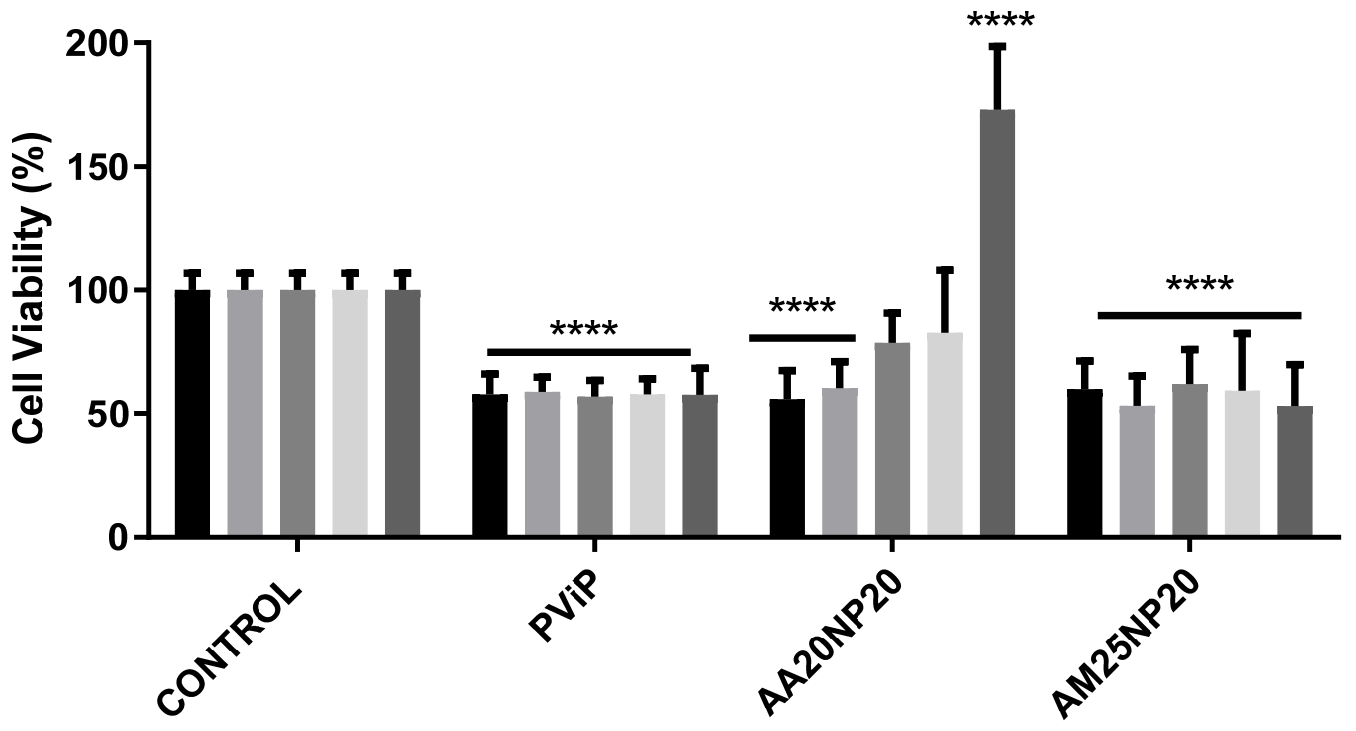

$0.01 \mathrm{mg} / \mathrm{mL}$

$0.05 \mathrm{mg} / \mathrm{mL}$

$0.1 \mathrm{mg} / \mathrm{mL}$

$0.25 \mathrm{mg} / \mathrm{mL}$

$0.5 \mathrm{mg} / \mathrm{mL}$

(A)

Figure 8. Cont. 

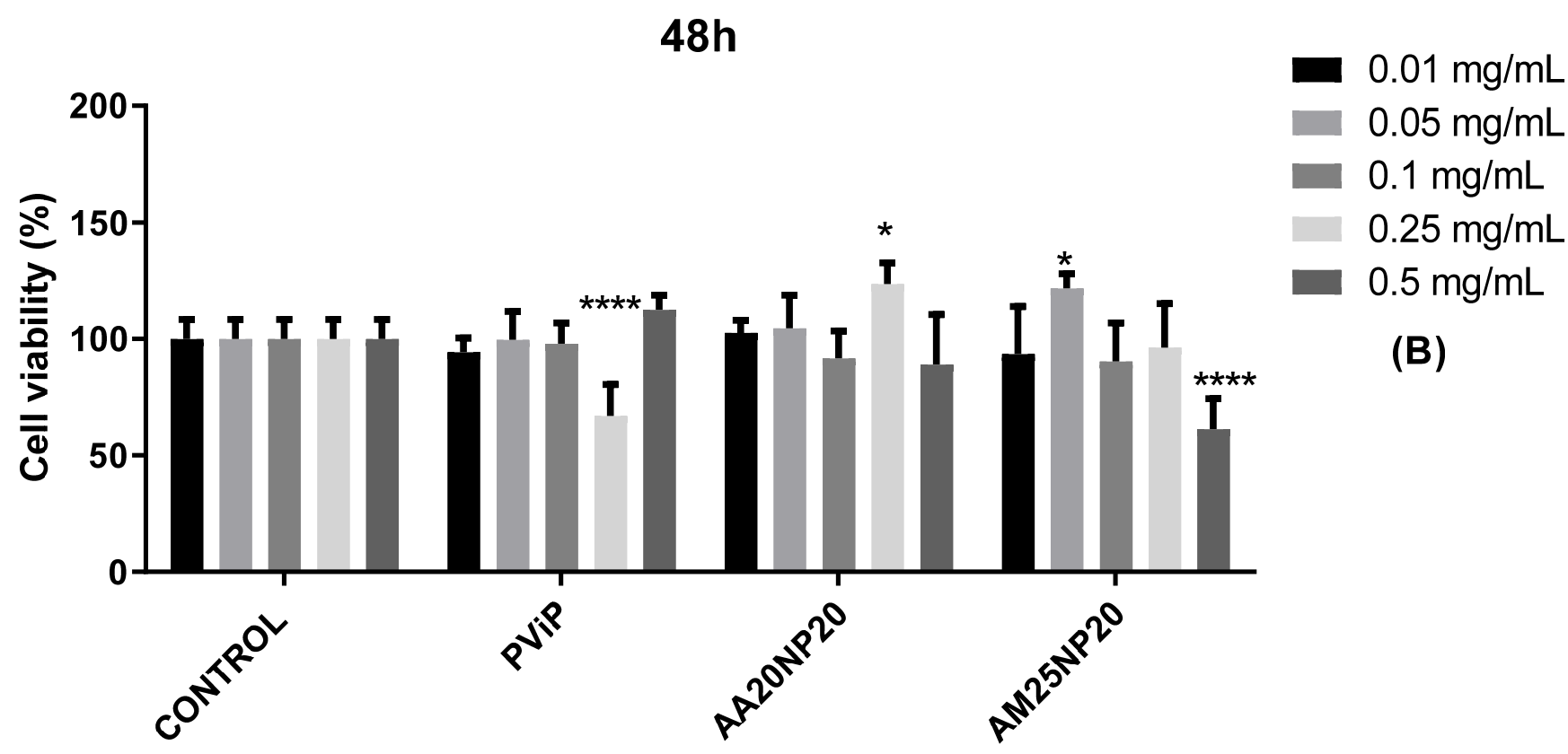

(B)

\section{$72 \mathrm{~h}$}

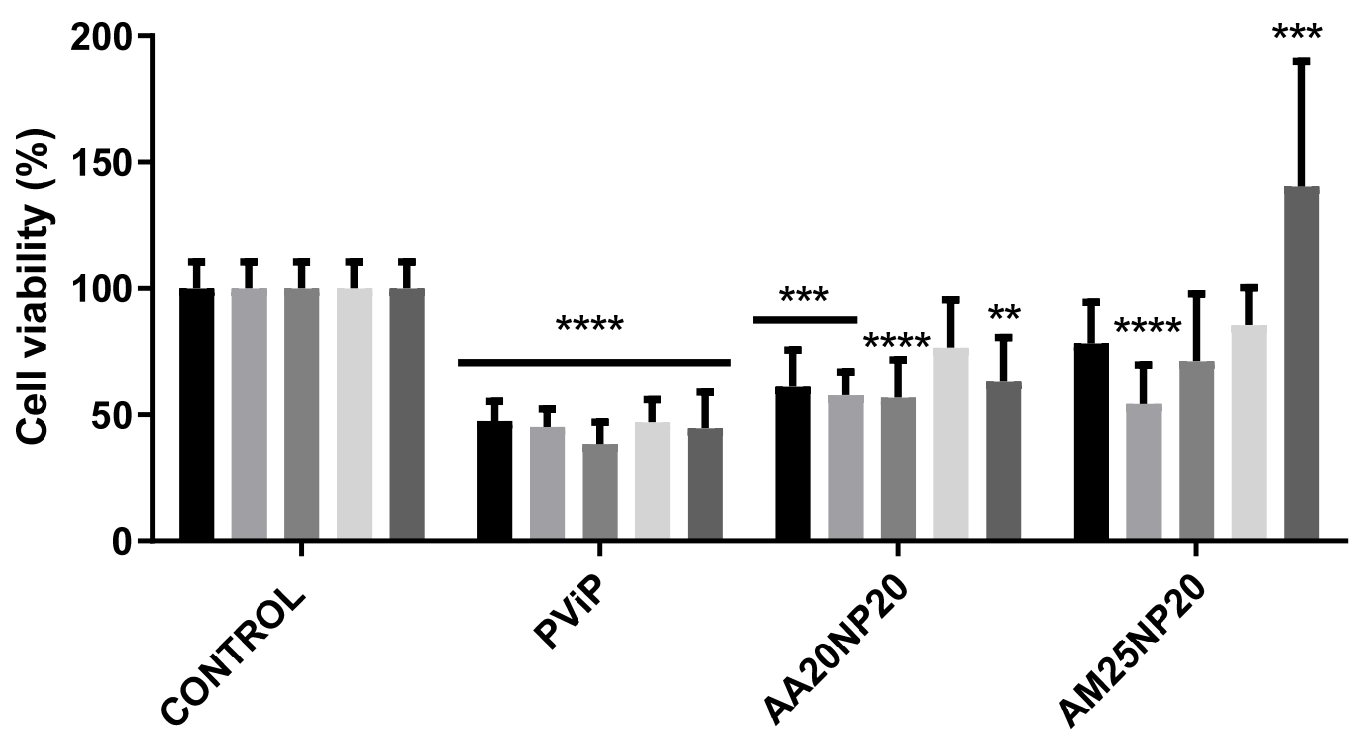

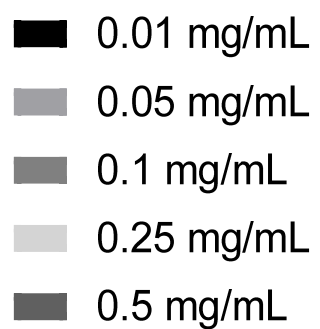

(C)

Figure 8. Evaluation of the cytotoxic activity of the polymer samples on human keratinocyte (HaCaT) cells after (A) 24, (B) 48, and (C) $72 \mathrm{~h}$ exposure at the particle concentrations of $0.01,0.05,0.1,0.25$, and $0.5 \mathrm{mg} / \mathrm{mL}$. Asterisks are related to different confidence intervals associated with statistical significance: * $95 \%$ with $p \leq 0.05, * * 99 \%$ with $p \leq 0.01$, *** $99.9 \%$ with $p \leq 0.001$, and **** $99.99 \%$ with $p \leq 0.0001$.

\subsection{A431 lineage Cell Viability}

A third tumor lineage used in this study was that of non-melanoma skin cancer (A431), which was also tested under the same conditions as the two non-tumor lines mentioned above. At a $24 \mathrm{~h}$ time period, there was a reduction of $30-50 \%$ for all concentrations in sample 1 (PViP), while in sample 2 (AA20NP20), only at the concentration of $0.1 \mathrm{mg} / \mathrm{mL}$ was it significant with approximately $30 \%$, and the others showed no changes. For sample 3 (AM25NP20), only concentrations of 0.05 and $0.1 \mathrm{mg} / \mathrm{mL}$ showed a reduction of approximately 30\% for both (Figure 9 ). 
For $48 \mathrm{~h}$ treatment of this strain, toxicity was obtained for all samples ranging from $20 \%$ to $50 \%$ in the analyzed concentrations; whereas in sample 1, the most significant result was found in the concentration $0.1 \mathrm{mg} / \mathrm{mL}$ with $70 \%$. in Sample 2, viability was $70 \%$ for the first four concentrations, and in Sample 3, the highest concentration was approximately $40 \%$.

\section{$24 \mathrm{~h}$}

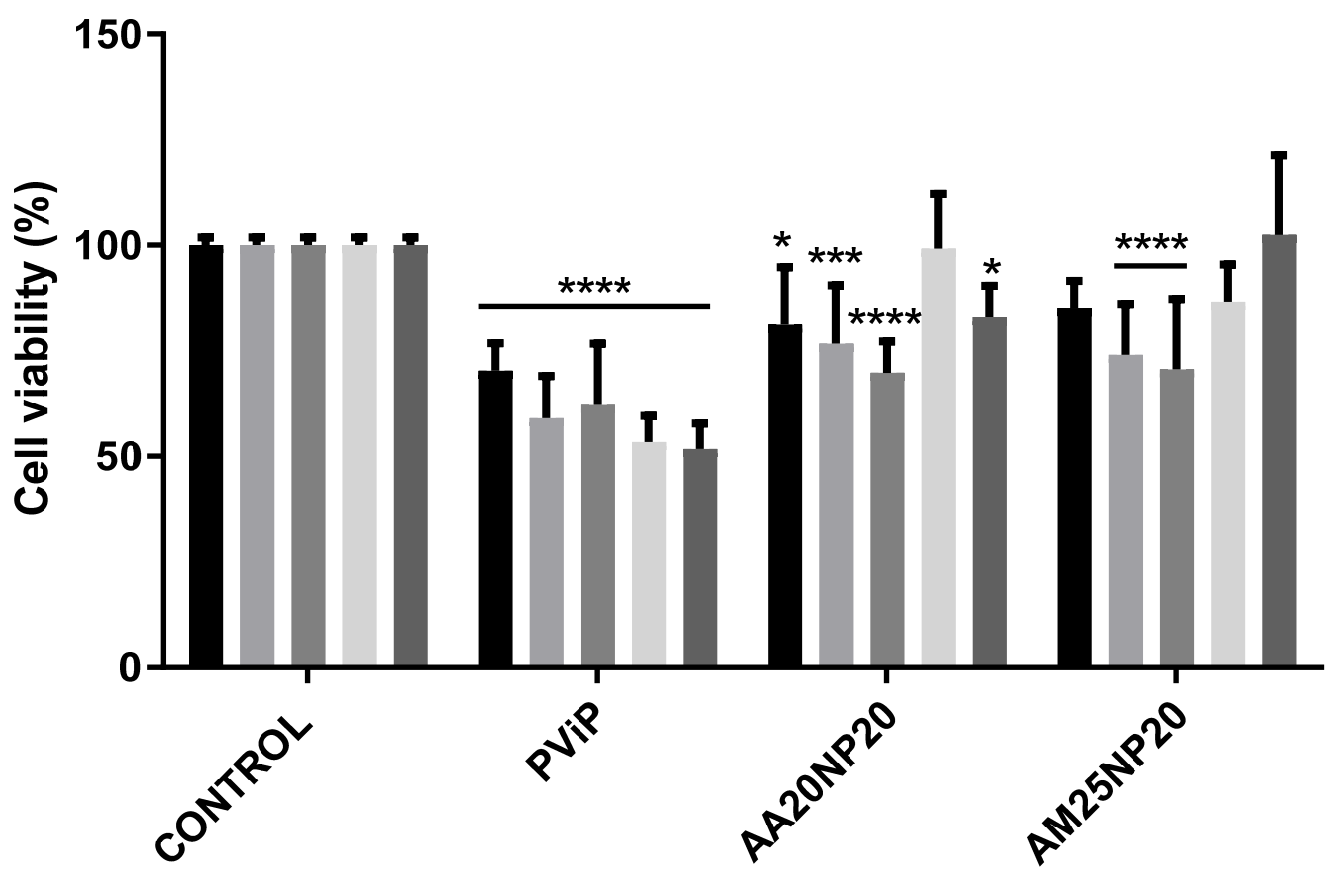

- $0.01 \mathrm{mg} / \mathrm{mL}$ $0.05 \mathrm{mg} / \mathrm{mL}$ $0.1 \mathrm{mg} / \mathrm{mL}$ $0.25 \mathrm{mg} / \mathrm{mL}$ $0.5 \mathrm{mg} / \mathrm{mL}$ (A)

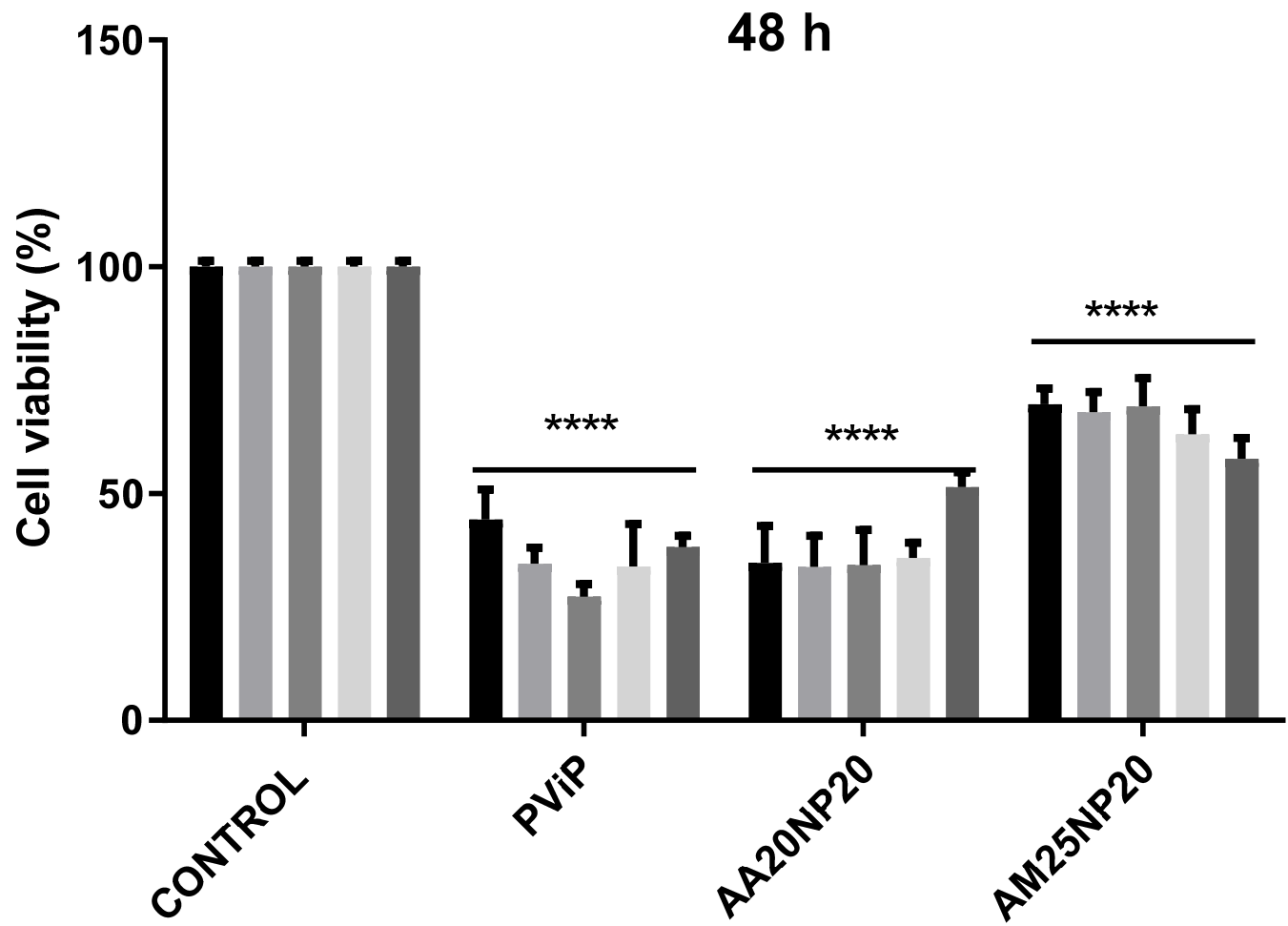

- $0.01 \mathrm{mg} / \mathrm{mL}$ $0.05 \mathrm{mg} / \mathrm{mL}$ $0.1 \mathrm{mg} / \mathrm{mL}$ $0.25 \mathrm{mg} / \mathrm{mL}$ $0.5 \mathrm{mg} / \mathrm{mL}$

(B)

Figure 9. Cont. 


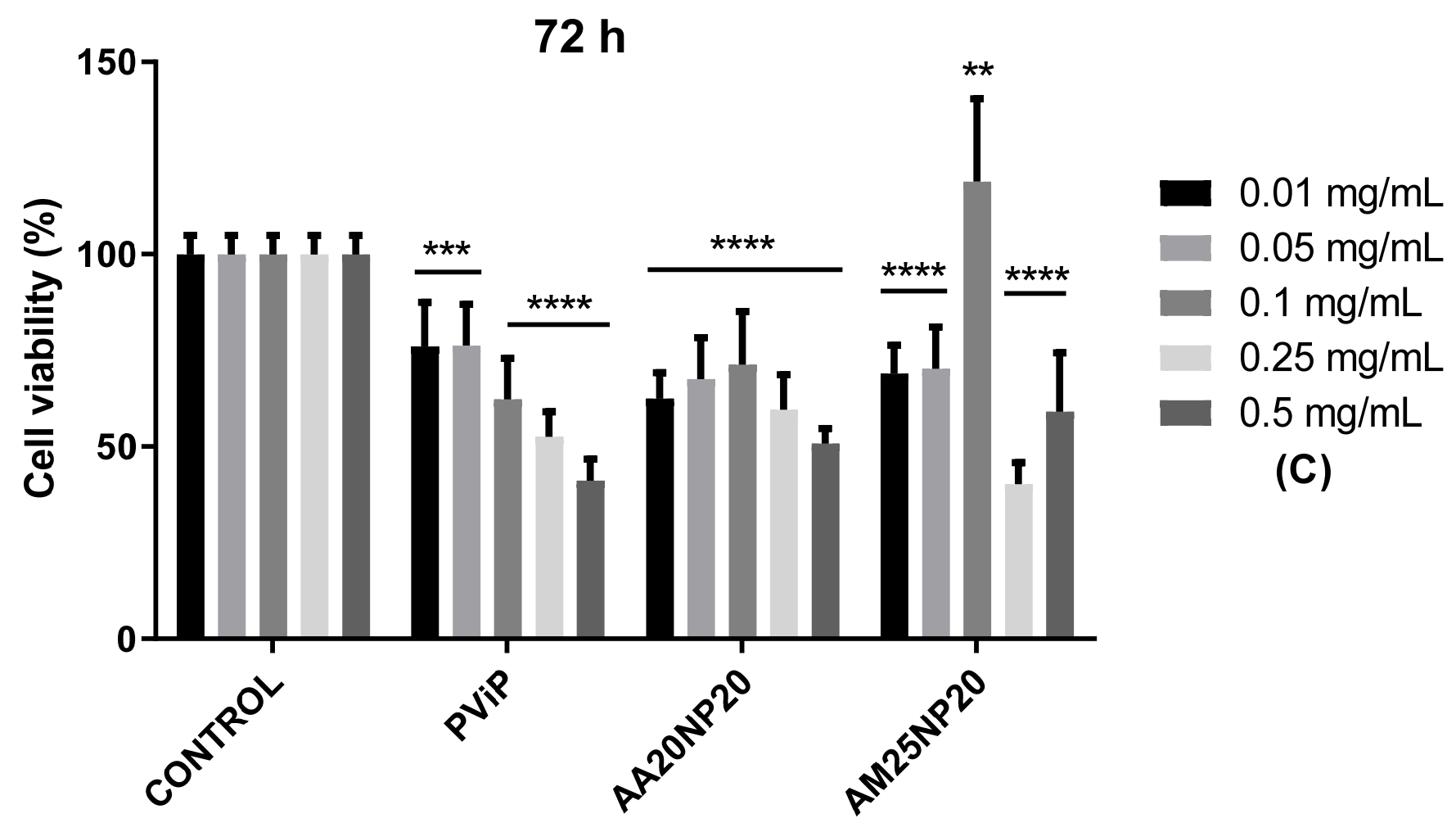

Figure 9. Evaluation of cytotoxic activity of the polymer samples on human (A431) non-melanoma skin cancer cells (NMSCCs) after (A) 24, (B) 48, and (C) $72 \mathrm{~h}$ exposure at the particle concentrations of $0.01,0.05,0.1,0.25$, and $0.5 \mathrm{mg} / \mathrm{mL}$. Asterisks are related to different confidence intervals associated with statistical significance: *95\% with $p \leq 0.05, * * 99 \%$ with $p \leq 0.01$, ** $99.9 \%$ with $p \leq 0.001$, and **** 99.99\% with $p \leq 0.0001$.

Based on the $72 \mathrm{~h}$ treatment data, it is possible to observe that the viability ranged from $25 \%$ to $60 \%$ in sample 1 with the highest toxicity being the highest concentration for sample 2, and there was no significant reduction for concentrations in the last two, only the toxicity was approximately $50 \%$. In sample 3, only at the concentration of $0.25 \mathrm{mg} / \mathrm{mL}$ was there a significant decrease of $60 \%$.

Encapsulation of nanoparticles showed an improvement in the thermal stability and biocompatibility of nanoparticles. Under this point of view, in vitro assays were realized with different cell lineages and did not present representative toxicity for non-tumor cells, which may be used for other biological studies, such as in vivo tests, with a more specific purpose for determining cell damage in concentrations where cell reduction was significant, but the other concentrations used did not show any damage, being considered as potential substances to be used associated with other substances without damage to the human organism. It is agreed that the potential for using these materials in biomedical application strongly depends on their cytotoxicity ability. In accordance with International Organization for Standardization (ISO 10993-5:2009) [43], materials exhibiting a cell viability greater than or equal to $70 \%$ in relation to the control group (100\% viability) can be considered non-cytotoxic.

\section{Conclusions}

The polymerization technique proposed in this work was capable of encapsulating magnetic nanoparticles using poly(vinyl pivalate) as polymeric matrix. The experimental results indicated the formation of the spinel phase of magnetite nanoparticles with a uniform size distribution with a mean size of approximately $6-8 \mathrm{~nm}$, good magnetic properties, high saturation magnetization (approximately $30-81 \mathrm{emu} / \mathrm{g}$, depending on the magnetite fraction), and superparamagnetic behavior at room temperature. Furthermore, the super- 
paramagnetic properties, which are important for applications, such as hyperthermia and embolization, did not change after the emulsion polymerization process.

It was demonstrated that the magnetite nanoparticles were properly and individually encapsulated using polymerizable carboxylic acids, such as acrylic acid and methacrylic acid, as coating agents, which can improve the magnetic response of the magneto-polymeric materials and, additionally, minimize the leaching of magnetite during the nanocomposite synthesis.

According to cytotoxicity assays, the high cell viability indicated that the biomedical application possibilities are promising, since the performance of the synthesized polymeric materials were satisfactory against fibroblast (FIBRO), human keratinocyte (HaCaT), and non-melanoma skin cancer (A431), exhibiting cell viabilities greater than $70 \%$ towards the cell lineages used in the study.

Author Contributions: R.T.A., M.S.B.N., J.A.H.C., S.B.C. and F.M. conceived and designed the experiments, analyzed the data, and wrote the paper; R.T.A., M.S.B.N. and J.A.H.C. performed the experiments. All authors have read and agreed to the published version of the manuscript.

Funding: This research received no external funding.

Acknowledgments: This work was supported by the Fundação de Apoio à Pesquisa do Distrito Federal (FAPDF) (Process: 0193.001523/2016), Conselho Nacional de Desenvolvimento Científico e Tecnológico (CNPq) (Process: 313361/2018-5 and Process: 409451/2016-9), and the Coordenação de Aperfeiçoamento de Pessoal de Nível Superior (CAPES) (Finance Code: 001). We would like to thank the Laboratório de Difratometria de Raios X (IG/UnB) for processing samples of pure materials and nanocomposites and the Laboratório de Criogenia (IF/UnB) for supplying liquid nitrogen to carry out the DSC analysis.

Conflicts of Interest: The authors declare no conflict of interest.

\section{References}

1. Laurent, S.; Forge, D.; Port, M.; Roch, A.; Robic, C.; Elst, L.V.; Muller, R.N. Magnetic Iron Oxide Nanoparticles: Synthesis, Stabilization, Vectorization, Physicochemical Characterizations, and Biological Applications. Chem. Rev. 2008, 108, 2064-2110. [CrossRef]

2. Mahmoudi, M.; Sant, S.; Wang, B.; Laurent, S.; Sen, T. Superparamagnetic iron oxide nanoparticles (SPIONs): Development, surface modification and applications in chemotherapy. Adv. Drug Deliv. Rev. 2011, 63, 24-46. [CrossRef]

3. Andrzejewski, B.; Bednarski, W.; Kazmierczak., M.; Pogorzelec-Glas, K.; Hilczer, B.; Jurga, S.; Matczak, M.; Łeska, B.; Pankiewicz, R.; Kepinski, L. Magnetization Enhancement in Magnetite Nanoparticles capped with Alginic Acid. Compos. Part B 2014, 147, 20. [CrossRef]

4. Bohara, R.A.; Thorat, N.B.; Pawar, S.H. Role of functionalization: Strategies to explore potential nano-bio applications of magnetic nanoparticles. RSC Adv. 2016, 6, 43989-44012. [CrossRef]

5. Ma, Z.; Liu, H. Synthesis and surface modification of magnetic particles for application in biotechnology and biomedicine. China Particuology 2007, 5, 1-10. [CrossRef]

6. Zhang, F.; Zhu, Z.; Dong, Z.; Cui, Z.; Wang, H.; Hu, W.; Zhao, P.; Wang, P.; Wei, S.; Li, R.; et al. Magnetically recoverable facile nanomaterials: Synthesis, characterization and application in remediation of heavy metals. Microchem. J. 2011, 98, 328-333. [CrossRef]

7. Togashi, T.; Naka, T.; Asahina, S.; Sato, K.; Takami, S.; Adschiri, T. Surfactant-assisted one-pot synthesis of superparamagnetic magnetite nanoparticle clusters with tunable cluster size and magnetic field sensitivity. Dalton Trans. 2011, 40, 1073-1078. [CrossRef] [PubMed]

8. Ali, A.; Zafar, H.; Zia, M.; Haq, I.U.; Phull, A.R.; Ali, J.S.; Hussain, A. Synthesis, characterization, applications, and challenges of iron oxide nanoparticles. Nanotechnol. Sci. Appl. 2016, 9, 49-67. [CrossRef]

9. Allen, T.M.; Cullis, P.R. Drug Delivery Systems: Entering the Mainstream. Science 2004, 303, 1818-1822. [CrossRef]

10. Souza, W.F.; Pereira, M.C.; Oliveira, L.C.A. Amphiphilic catalysts based on onion-like carbon over magnetic iron oxide for petrochemical industry use. Fuel 2012, 96, 604-607. [CrossRef]

11. Kaur, P.; Aliru, M.L.; Chadha, A.S.; Asea, A.; Krishnan, S. Hyperthermia Using Nanoparticles-Promises and Pitfalls. Int. J. Hyperth. 2016, 32, 76-88. [CrossRef] [PubMed]

12. Rafieepour, A.; Azari, M.R.; Peirovi, H.; Khodagholi, F.; Jaktaji, J.P.; Mehrabi, Y.; Naserzadeh, P.; Mohammadian, Y. Investigation of the effect of magnetite iron oxide particles size on cytotoxicity in A549 cell line. Toxicol. Ind. Health 2019, 35, 703-713. [CrossRef]

13. Prousek, J. Fenton chemistry in biology and medicine. Pure Appl. Chem. 2007, 79, 12. [CrossRef] 
14. Resende, G.; Dutra, G.V.S.; Neta, M.S.B.; Araújo, O.A.; Chaves, S.B.; Machado, F. Well Defined Poly(Methyl Methacrylate)Fe3O4/Poly(Vinyl Pivalate) Core-Shell Superparamagnetic Nanoparticles: Design and Evaluation of In Vitro Cytotoxicity Activity against Cancer Cells. Polymers 2020, 12, 2868. [CrossRef] [PubMed]

15. Rehana, D.; Haleel, A.K.; Rahiman, K. Hydroxy, carboxylic and amino acid functionalized superparamagnetic iron oxide nanoparticles: Synthesis, characterization and In Vitro anti-cancer studies. J. Chem. Sci. 2015, 127, 1155-1166. [CrossRef]

16. Sahu, D.; Kannan, G.M.; Tailang, M.; Vijayaraghavan, R. In Vitro Cytotoxicity of Nanoparticles: A Comparison between Particle Size and Cell Type. J. Nanosci. 2016, 2016, 023852. [CrossRef]

17. Ma, Z.; Bai, J.; Jiang, X. Monitoring of the Enzymatic Degradation of Protein Corona and Evaluating the Accompanying Cytotoxicity of Nanoparticles. ACS Appl. Mater. Interfaces 2015, 7, 17614-17622. [CrossRef]

18. Vazquez-Muñoz, R.; Borrego, B.; Juárez-Moreno, K.; García-García, M.; Morales, J.D.M.; Bogdanchikova, N.; Huerta-Saquero, A. Toxicity of silver nanoparticles in biological systems: Does the complexity of biological systems matter? Toxicol. Lett. 2017, 276, 11-20. [CrossRef]

19. Neto, W.S.; Dutra, G.V.S.; Jensen, A.T.; Araújo, O.A.; Garg, V.; de Oliveira, A.C.; Valadares, L.F.; de Souza, F.G., Jr.; Machado, F. Superparamagnetic nanoparticles stabilized with free-radical polymerizable oleic acid-based coating. J. Alloy. Compd. 2018, 739, 1025-1036. [CrossRef]

20. Aguilar-Arteaga, K.; Rodriguez, J.A.; Barrado, E. Magnetic solids in analytical chemistry: A review. Anal. Chim. Acta 2010, 674, 157-165. [CrossRef] [PubMed]

21. Agrawal, D.C.; Maity, D. Synthesis of iron oxide nanoparticles under oxidizing environment and their stabilization in aqueous and non-aqueous media. J. Magn. Magn. Mater. 2007, 308, 46-55. [CrossRef]

22. Araújo-Neto, R.P.; Silva-Freitas, E.L.; Carvalho, J.F.; Pontes, T.R.F.; Silva, K.L.; Damasceno, I.H.M.; Egito, E.S.T.; Dantas, A.L.; Morales, M.A.; Carriço, A.S. Monodisperse sodium oleate coated magnetite high susceptibility nanoparticles for hyperthermia applications. J. Magn. Magn. Mater. 2014, 364, 72-79. [CrossRef]

23. Lobato, N.C.C.; Mansur, M.B.; Ferreira, A.M. Characterization and Chemical Stability of Hydrophilic and Hydrophobic Magnetic Nanoparticles. Mater. Res. 2017, 20, 736-746. [CrossRef]

24. Carvalho, M.D.; Henriques, F.; Ferreira, L.P.; Godinho, M.; Cruz, M.M. Iron oxide nanoparticles: The Influence of synthesis method and size on composition and magnetic properties. J. Solid State Chem. 2013, 201, 144-152. [CrossRef]

25. Vereda, F.; de Vicente, J.; Morales, M.d.P.; Rull, F.; Hidalgo-Álvarez, R. Synthesis and Characterization of Single-Domain Monocrystalline Magnetite Particles by Oxidative Aging of $\mathrm{Fe}(\mathrm{OH})_{2}$. J. Phys. Chem. C 2008, 112, 5843-5849. [CrossRef]

26. Mahmed, N.; Heczko, O.; Lancok, A.; Hannula, S.P. The magnetic and oxidation behavior of bare and silica-coated iron oxide nanoparticles synthesized by reverse co-precipitation of ferrous ion $\left(\mathrm{Fe}^{2+}\right)$ in ambient atmosphere. J. Magn. Magn. Mater. 2014, 353, 15-22. [CrossRef]

27. Christopher, A.G.; Scherer Michelle, M. Determination of nanoparticulate magnetite stoichiometry by Mössbauer spectroscopy, acidic dissolution, and powder X-ray diffraction: A critical review. Am. Mineral. 2010, 95, 1017. [CrossRef]

28. Lu, A.-H.; Salabas, E.; Schüth, F. Magnetic Nanoparticles: Synthesis, Protection, Functionalization, and Application. Angew. Chem. Int. Ed. 2007, 46, 1222-1244. [CrossRef]

29. Salmimies, R.; Mannila, M.; Kallas, J.; Hakkinen, A. Acidic dissolution of magnetite: Experimental study on the effects of acid concentration and temperature. Clays Clay Miner. 2011, 59, 136-146. [CrossRef]

30. Ortiz, N.; Susca, C.; de Oliveira, K.M.R.; Bressiani, J.C. Study of the chemical stability of the magnetite used as adsorber to remove organic compounds from solutions. Cerâmica 2003, 49, 216-222. [CrossRef]

31. Radońa, A.; Łoński, S.; Kądziołka-Gaweł, M.; Gębara, P.; Lis, M.; Łukowiec, D.; Babilas, R. Influence of magnetite nanoparticles surface dissolution, stabilization and functionalization by malonic acid on the catalytic activity, magnetic and electrical properties. Colloids Surf. A Physicochem. Eng. Asp. 2020, 607, 125446. [CrossRef]

32. Schwaminger, S.P.; Syhr, C.; Berensmeier, S. Controlled Synthesis of Magnetic Iron Oxide Nanoparticles: Magnetite or Maghemite? Crystals 2020, 10, 214. [CrossRef]

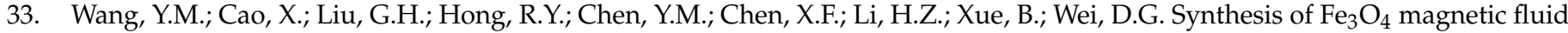
used for magnetic resonance imaging and hyperthermia. J. Magn. Magn. Mater. 2011, 323, 2953-2959. [CrossRef]

34. Gnanaprakash, G.; Philip, J.; Jayakumar, T.; Raj, B. Effect of Digestion Time and Alkali Addition Rate on Physical Properties of Magnetite Nanoparticles. J. Phys. Chem. B 2007, 111, 7978-7986. [CrossRef]

35. Bonvin, D.; Hofmann, H.; Ebersold, M.M. Optimisation of aqueous synthesis of iron oxide nanoparticles for biomedical applications. J. Nanoparticle Res. 2016, 18, 376. [CrossRef]

36. Imada, M.; Fujimori, A.; Tokura, Y. Metal-insulator transitions. Rev. Mod. Phys. 1998, 70, 1039. [CrossRef]

37. Zhang, X.; Chen, L.; Yuan, L.; Liu, R.; Li, D.; Liu, X.-P.; Ge, G. Conformation-Dependent Coordination of Carboxylic Acids with $\mathrm{Fe}_{3} \mathrm{O}_{4}$ Nanoparticles Studied by ATR-FTIR Spectral Deconvolution. Langmuir 2019, 35, 5770-5778. [CrossRef]

38. Li, Q.; Kartikowati, C.W.; Horie, S.; Ogi, T.; Iwaki, T.; Okuyama, K. Correlation between particle size/domain structure and magnetic properties of highly crystalline $\mathrm{Fe}_{3} \mathrm{O}_{4}$ nanoparticles. Sci. Rep. 2017, 7, 9894. [CrossRef]

39. Daoush, W.M. Co-Precipitation and Magnetic Properties of Magnetite Nanoparticles for Potential Biomedical Applications. J. Nanomed. Res. 2017, 5, 00118. [CrossRef]

40. Abdolrahimi, M.; Vasilakaki, M.; Slimani, S.; Ntallis, N.; Varvaro, G.; Laureti, S.; Meneghini, C.; Trohidou, K.N.; Fiorani, D.; Peddis, D. Magnetism of Nanoparticles: Effect of the Organic Coating. Nanomaterials. Nanomaterials 2021, 11, 1787. [CrossRef] 
41. Yuan, Y.; Rende, D.; Altan, C.L.; Bucak, S.; Ozisik, R.; Borca-Tasciuc, D.-A. Effect of Surface Modification on Magnetization of Iron Oxide Nanoparticle Colloids. Langmuir 2012, 28, 13051-13059. [CrossRef] [PubMed]

42. Corrêa, B.S.; Costa, M.S.; Cabrera-Pasca, G.A.; Sena, C.; Pinto, R.H.H.; Silva, A.P.S.; Junior, R.N.C.; Ishida, L.; Ramon, J.G.A.; Freitas, R.S.; et al. High-saturation magnetization in small nanoparticles of $\mathrm{Fe}_{3} \mathrm{O}_{4}$ coated with natural oils. J. Nanoparticle Res. 2020, 22, 15. [CrossRef]

43. ISO10993-5; Biological Evaluation of Medical Devices. Part 5: Tests for In Vitro Cytotoxicity; International Organization for Standardization: Geneva, Switzerland, 2009; p. 34. 